\title{
»Præsident« Topff og republikken Als - endnu engang
}

Af Dorrit Andersen

I 1984 har Bruno Topff Selskabet i Sønderborg udgivet en lille bog, nemlig Robert Huhle: Bruno Gustav Eugen Topff og revolutionen i Sønderborg. Foranlediget heraf gennemgås $\mathrm{i}$ denne artikel de vigtigste kilder til revolutionsforløbet i Sønderborg 1918, og på flere punkter vurderes begivenhederne anderledes end i Robert Huhles bog. Afsluttende bringes en del nye oplysninger om Topffs virksomhed i Sønderborg efter revolutionen.

\section{Skiftende syn på "præsident« Topff}

Den 12. november 1920 indeholdt avisen Dybbøl-Posten følgende nekrolog over én af Sønderborgs borgere:

"En ret bevæget skæbne er i tirsdags afsluttet på det herværende invalidehospital, idet tidligere skræddersvend Bruno Topff er afgået ved døden. Den afdøde, som i det sidste års tid havde været svagelig, idet han led af tuberkulose, stammede fra Berlin og kom hertil under krigen. Han opnåede, hvad ingen anden kan rose sig af at have været, nemlig at blive proesident for republikken Als, om end kun for en dag eller to.

Da revolutionen brød ud her i novemberdagene for to år siden, var Topff marinesoldat. Hvordan det er gået til, ved vi ikke, men den 6 . november 1918 proklameredes Als som republik med Bruno Topff som præsident. Det første, den nye præsident anskaffede sig, var et automobil, og med en rød vimpel foran fór han frem og tilbage i gaderne i Sønderborg for at inspicere og styre sit riges hovedstad. I næsten halvandet døgn var han højstkommanderende over alle de militære styrker til lands og til vands, som lå i Sønderborg.

Han begyndte straks at regere, og hans form for regeringshandlinger nåede ikke ud over proklamationernes stadium. Han fik dog lejlighed 
til at udstede flere. Han stævnede blandt andre daværende landråd Schönberg for sig, som førtes ind under militær bevogtning. På det nye "regeringskontor" fik han at vide, at han kunne fortsætte sin embedsvirksomhed foreløbig, men at alle hans proklamationer også måtte underskrives af præsidenten, for at de kunne være gyldige. Audiensen skal være forløbet tilfredsstillende og, når man ser bort fra ęt enkelt dramatisk optrin, også ret rolig.

Dagen efter ophørte Als med at være republik, og ekspræsidenten gled foreløbig ud af den politiske saga. Hans vigtigste regeringshandling bestod $i$, at han straks lod al udførsel fra øen standse og uddelte et halvt pund smør pr. hoved, noget på det tidspunkt aldeles uhørt, som nok ville have været $\mathrm{i}$ stand til at fæstne en mands politiske stilling«.

Denne nekrolog er, så vidt det har kunnet konstateres, den første samlede beskrivelse af revolutionsforløbet i Sønderborg, og må antages at afspejle samtidens indtryk af begivenhederne. Samtidig er den et af de første steder, hvor Topff betegnes som præsident for republikken Als. Fra selve revolutionsdagene findes nemlig ingen vidnedbyrd herom. Derfor har mange senere overvejelser beskæftiget sig med, om traditionen bygger på en solid kerne, eller om den er udtryk for en mytedannelse.

Der er skrevet umådelig meget om revolutionen i Sønderborg, og i det følgende skal de vigtigste bidrag omtales. De foreliggende erindringsbidrag er normalt beklageligvis blevet til meget længe efter begivenhederne og kan derfor kun anvendes med største forsigtighed. Ét fortjener dog at blive fremhævet, nemlig gårdejer Ernst Christensens artikel i Danebod Højskoles årsskrift 1928, »Hvad der skete for ti Aar siden «. Heri skildrer han sine oplevelser i forbindelse med en audiens hos Topff, hvis præsidentværdighed han ikke drager i tvivl. Dette relativt tidlige erindringsbidrag har med rette været meget brugt i skildringer af revolutionen i Sønderborg.

Den første egentlige historiske behandling af emnet finder vi i Frede Nielsens værk »Fra Udmark til Forpost. Den sønderjydske Arbejderbevægelses Historie«, der udkom i 1938. Frede Nielsen har her bl.a. kunnet bygge på den lokale tradition i arbejderbevægelsen om begivenhederne og drager ikke republikkens eksistens i tvivl. Dette sker først i en artikel i Sønderjyske Årbøger 1965, nemlig Kaj Rolfsen Nissen: „Problemer omkring "Præsident« Topff««. Nissen har gennemgået aviserne fra revolutionsdagene og dér ikke fundet nogen omtale af oprettelsen af en republik. Deraf slutter han, at traditionen om Als som republik er en myte. Han mener dog også, at man kan sige, at Topff 
optrådte temmelig egenrådigt. Nissen har imidlertid langt fra udnyttet alt det eksisterende kildemateriale om begivenhederne, så der er flere momenter i sagen, der bør inddrages. Samtidig med, at han vil nedbryde én myte, lægger han grunden til en ny, nemlig ved en kolossalt positiv vurdering af Topffs virke og person, der ses i et forklaret, revolutionsromantisk skær. Hvor samtidens kilder tier på dette punkt, fyldes hullerne ud med fantasiens hjælp i en velskrevet og grebet fremstilling.

Året efter fremkom en korrektion i Sønderjyske Årbøger. A. Thyssen fortæller i en lille artikel med titlen »Omkring »Præsident « Topff, Sønderborg«", at han selv har overværet, at Topff udråbte republikken Als. Hvad skal man så tro på? Skal man holde sig til, hvad der har stået eller ikke stået i avisen, eller skal man tro på den mand, der siger, at han selv har hørt det? Thyssens udsagn har ikke givet meget genklang, fordi det er skrevet så mange år efter begivenhederne. Hukommelsen er som bekendt skrøbelig, og der har ikke meldt sig andre vidner til proklamationen. De soldater, der har overværet begivenhederne, har for størstedelens vedkommende ikke været fra landsdelen og er blevet hjemsendt i månederne efter. Allerede i 1966 måtte man gå ud fra, at de fleste var døde. Thyssen mente da også, at han var det eneste nulevende vidne.

I 1972 beskæftigede jeg mig selv med Topffepisoden i Sønderjyske Årbøger i artiklen Rådsbevægelsen i Nordslesvig 1918-20. Der kunne heri fremlægges en del nyt kildemateriale; men konklusionen kunne ikke give et klart ja eller nej svar på spørgsmålet om republik eller ej. De atypiske træk i forhold til revolutionsforløbet andre steder i landsdelen blev fremhævet, og eksistensen af republikken blev ikke totalt afvist; men det mentes at være forsvarligt at fastslå, at der havde været tale om en kortvarig diktaturperiode, der formentlig måtte bringes til ophør på grund af indre modsætninger i soldaterrådet og indgriben fra revolutionsledelsen i Kiel. Inden for rammerne af en generel beskrivelse af rådsbevægelsen $\mathrm{i}$ Nordslesvig kunne behandlingen af forholdene $\mathrm{i}$ Sønderborg ikke blive særlig detaljeret; men afhandlingens udførlige kilde- og litteraturhenvisninger kunne give et udgangspunkt for en mere gennemgribende skildring af begivenhederne. Henvisningerne blev således brugt til at skaffe materiale til en eksamensopgave i historisk metode ved Aarhus Universitet i 1974. I besvarelsen af opgaven skulle der specielt tages stilling til spørgsmålet om, hvorvidt Als proklameredes som republik. Opgaven og dermed centrale kilder er trykt 1978 i publikationen Kildekritisk Tekstsamling (udg. af Jysk Selskab for Historie). 
En del af kildematerialet fra afhandlingen om rådsbevægelsen er også benyttet i Robert Huhles skrift fra 1984 med titlen »Bruno Gustav Eugen Topff og revolutionen i Sønderborg«, der er udgivet af Bruno Topff Selskabet i Sønderborg. I forbindelse hermed er der også samlet en del erindringsstof; men, som det var at vente så mange år efter begivenhederne, synes disse erindringer ikke at have bragt afgørende nyt frem. Robert Huhle afviser med henvisning til Nissens ovenfor omtalte arbejde enhver sandsynlighed for proklamering af republikken Als. Men han går videre endnu. Mens Nissen ikke ville afvise egenrådighed fra Topffs side i revolutionsdagene, er Huhles bog nærmest et rendyrket forsvarsskrift for Topff. Alt, hvad der kan tale imod en glorificering af Topff, afvises eller bagatelliseres. Kilder, der ikke passer i Huhles kram, synes at stamme fra personer med en skidt karakter eller er i bedste fald ligegyldige. I betragtning af, at skriftet nærmest skal ses som konklusionen på selskabets årelange beskæftigelse med Bruno Topffs virke, er det uhensigtsmæssigt, at det ikke er forsynet med mere præcise kilde- og litteraturhenvisninger til vejledning for den interesserede læser. Særlig savner man et overblik over de nye kilder, Bruno Topff Selskabet har søgt at samle om Topffs virke. Det er imidlertid ikke tanken $\mathrm{i}$ det følgende at gå i en detaljeret diskussion med Huhle. Derimod vil de samtidige kilders udsagn blive fremlagt, og forløbet $i$ Sønderborg vil blive sammenlignet med begivenhederne i Kiel, revolutionens centrum, og i Nordslesvig i øvrigt, således at læseren får mulighed for at danne sig sin egen opfattelse af det langt fra entydige og sparsomme kildemateriale, vi i dag har til rådighed. Afsluttende skal der fortælles lidt om Bruno Topffs senere politiske virke i Sønderborg, således som det fremgår af spredte avisreferater, et virke, jeg ikke inden for rammerne af artiklen om rådsbevægelsen havde mulighed for at gå nærmere ind på.

Hverken Huhles skrift eller mine kommentarer kan imidlertid siges at gøre krav på at være den endelige sandhed om begivenhederne. I forhold til min artikel fra 1972 er der kun fundet meget lidt nyt kildemateriale $\mathrm{i}$ arkiverne siden; men dette er naturligvis søgt medtaget her. Der vil fortsat være meget store huller i vor viden om revolutionsdagene og Topffs liv derefter. Det skal ikke skjules i det følgende. Man kan heller ikke udelukke muligheden af, at der kan dukke yderligere oplysninger op om Topff i arkiver fra den tyske tid, i den senere danske statslige og lokale administrations arkiver og i aviserne. Her tænkes mest på oplysninger af personalhistorisk karakter. Sandsynligheden for at finde mere om revolutionsdagene er nok ikke stor. 
Før begivenhederne i Sønderborg behandles, er det imidlertid rimeligt kort at omtale, hvordan revolutionen i Kiel begyndte, da det er nødvendigt for at forstå, hvad der foregik lokalt i Sønderborg.

\section{Matrosopstanden i Kiel og den tyske republiks fødsel}

"Aldrig i historien er en så strålende og følgerig politisk omvæltning som den, der blev fremkaldt af matrosopstanden i Kiel, blevet opnået så hurtigt og forholdsvis ublodigt. Som et korthus faldt det tilsyneladende så fast sammenføjede tyske militærautokrati sammen «. Således skrev én af lederne i Kielopstanden allerede i november 1918 om de begivenheder, der førte til det tyske kejserdømmes fald.'

Allerede før opstanden begyndte der at ske ting, der indvarslede ændringer $i$ det tyske politiske system. En månedstid før, natten mellem den 3. og 4. oktober 1918 havde den tyske regering anmodet de allierede om våbenstilstand. Det var den tyske hærledelse, der nu så nederlaget $\mathrm{i}$ øjnene og lagde pres på kejseren. Den fik også gennemført en ny regering med socialdemokratisk deltagelse, Tysklands første parlamentariske regering. Den liberale prins Max af Baden blev lederen. Således fik det store socialdemokrati i nederlagets stund del i den regeringsmagt, som det altid havde været holdt udenfor. I det forestående nederlag var der brug for en større kreds, bl.a. socialdemokraterne, SPD, til at tage del i ansvaret og smerten. Våbenstilstandsbegæringen var stilet til den amerikanske præsident Wilson, der ikke opfattedes som så hævnlysten. Han havde imidlertid sine allierede at tage hensyn til. Svaret trak derfor ud. I flådeledelsen var man imidlertid indstillet på en slags mytteri mod denne linie. Flådeledelsens »mytteri« affødte mandskabets revolte mod flådeledelsen.

Der havde længe været mange tegn på, at krigstrætheden ikke blot var udbredt i civilbefolkningen og i hæren, men også blandt flådens mandskab. Men alligevel lagde flådeledelsen i hemmelighed planer om at sende flåden ud i Nordsøen i slutningen af oktober. Hensigten var at udkæmpe et afgørende, men måske også selvmorderisk slag mod den engelske flåde. I Wilhelmshaven gættede mandskabet imidlertid admiralernes hensigter og troede ikke på, at der blot skulle være tale om en manøvre. Om aftenen den 29. oktober var mytteriet igang, og selv om flådefremstødet blev afblæst den følgende dag, hørte lydighedsnægtelserne ikke op. En del af flåden blev beordret tilbage til Kiel, mere end tusinde mytterister blev arresteret og sendt til militærfængsler for at blive stillet for en krigsret. 
Llriprung und Entrvictlung Tobember:Récolution 1918. Woie die deutfchexepublif erftand. (1)

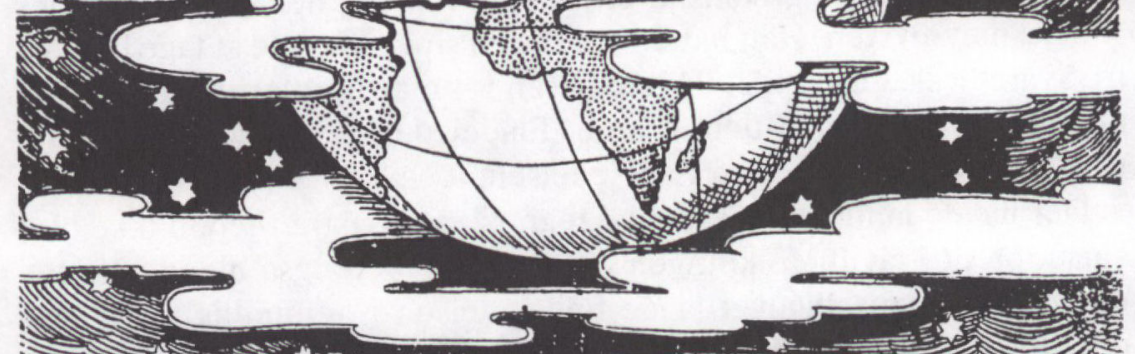
$=-$ unter Mitarbeit von Rarl 2urtelt, Dorfizende des Oberften Goldatenrates kiel. 
I Kiel bredte oprøret sig imidlertid med protestmøder mod arrestationerne, og den lokale arbejderbevægelse fandt hurtigt ind i et samvirke med de protesterende. Flådeledelsen mistede kontrollen med begivenhederne. Den 3 . november fandt et stort protestmøde sted med det primære formål at kræve fangernes frigivelse, og efter mødet blev der skudt på demonstrerende marinesoldater og arbejdere af soldater fra de sidste loyale tropper. Ni døde og et større antal sårede var resultatet.

Den følgende morgen valgte marinesoldaterne et soldaterråd, der i realiteten overtog magten, og dagen efter oprettedes arbejderrådet. Fra Kiel blev oprørsparolen hurtigt udbredt, og bevægelsen fik også nu en politisk tendens vendt imod kejserdømme og militarisme. I løbet af få dage omfattede bevægelsen hele riget. Om aftenen den 9. november udråbtes den tyske republik, og den følgende dag dannedes den første tyske arbejderregering. Våbenstilstanden fulgte den 11. november.

Den nye regering blev sammensat af repræsentanter for de to socialdemokratiske partier, nemlig de såkaldte flertalssocialister (SPD) og de uafhængige socialdemokrater (USPD). Dette parti befandt sig politisk til venstre for SPD og var oprettet i 1917 af oppositionelle socialdemokrater. Det var stærkt imod krigen, og imod SPD's efterhånden omfattende samarbejde med borgerlige partier og støtte til krigsførelsen.

Samarbejdet mellem de to partier varede ikke længe, da de ikke kunne nå til enighed om, hvordan den videre politiske udvikling skulle forme sig. Flertalssocialisterne og en del af de uafhængige mente, at det væsentligste mål var nået med indførelsen af republikken og magtovertagelsen. De havde nok i en slags borgerlig, demokratisk revolution. Arbejder- og soldaterrådene måtte de derfor opfatte som et overgangsfænomen, der skulle sikre, at forvaltningen nu fungerede $i$ demokratiets ånd. Flertallet i USPD var mere indstillet på en forsigtig socialisering og en bibeholdelse af rådssystemet under én eller anden form. Den 29. december 1918 trådte USPD-repræsentanterne ud af regeringen, som så blev en ren SPD-regering. Dagen efter forlod par-

I Tyskland begyndte en omfattende historieskrivning om Novemberrevolutionen allerede kort efter begivenhederne. Pd billedet ses säledes en pjece fra slutningen af 1918, forfattet af to af revolutionslederne $i$ Kiel. - Lige modsat forholder det sig med interessen for revolutionsforlobet $i$ Nordslesvig. Palidelige erindringer er der kun fà af, og den egentlige videnskabelige interesse for begivenhederne vàgnede sà sent, at meget kildemateriale ikke mere kunne indsamles. Vor viden om revolutionen i Sonderborg er således absolut ikke udtemmende. 
tiets venstrefløj, spartakisterne (kommunisterne) partiet og arbejdede videre for at gennemfore en revolutionær udvikling i Tyskland. Dette skabte borgerkrigslignende tilstande, og SPD-regeringen nedkæmpede med hård hånd de revolutionære. I sammenligning hermed fik partisplittelsen mere beskedne følger i Nordslesvig, som det senere skal omtales.

Det blev SPD og SPD's moderate politik, der høstede sejren efter de brogede revolutionsdage. Medvirkende til dette resultat var, at partiet meget hurtigt fik kontrol med oprørsbevægelsen i Kiel. Allerede den 4. november havde regeringen sendt to mand til Kiel for at finde ud af, hvad der foregik, og hvad der burde gøres. Den ene var den socialdemokratiske rigsdagsmand Gustav Noske (1868-1946). Han havde været rigsdagsmand siden 1906 og blev SPD's forsvarspolitiske ekspert. På grund af denne virksomhed havde han god kontakt til marinen og stod derfor også som et begreb for mange matroser. Han kan betegnes som en nationalt sindet højre-socialdemokrat, der ikke ønskede nogen voldelig ændring af samfundet. ${ }^{2}$ Samtidig viser hans indsats i revolutionsdagene ham som en mand med en betydelig handlekraft, autoritet og evne til at bevæge både gamle og nye magthavere til kompromisser. Hans virke skal kun omtales kort her. For en mere detaljeret redeg $\emptyset$ relse for revolutionsbegivenhederne i Kiel kan interesserede henvises til den udførlige og velskrevne fremstilling i Dirk Dähnhardt: Revolution in Kiel (1978).

Noske ankom til Kiel den 4. november om aftenen. Han kastede sig straks ud i en omfattende møde- og forhandlingsaktivitet. Dagen efter blev han valgt til leder af soldaterrådet, og den forvirring, bevægelsen havde befundet sig i, blev nu afløst af en fast ledelse. De allerede vundne resultater blev ikke sat overstyr. Her skal nævnes den vidtgående demokratisering af forholdene inden for militæret. Officererne forblev, men måtte erklære sig loyale over for den nye orden. Noske opnåede regeringens støtte til sin ledelse af bevægelsen. Den 7 . november blev han af et soldaterrådsmøde valgt til guvernør i Kiel. Guvernøren var leder af Marinestation der Ostsee og havde fra krigsudbruddet også haft den øverste civile myndighed i Kielområdet. Én for én meddelte provinsgarnisonerne Noske deres tilslutning, og at de ville følge hans anvisninger. Revolutionen i Slesvig-Holsten ledtes ind i rolige baner, og de mange nydannede råd anerkendte hurtigt Noskes førerskab. Samtidig modsatte Noske sig med held pres fra især USPDside om at lade provinsen Slesvig-Holsten udråbe til republik. Det var 
ikke alle steder, SPD fik et så fast greb om revolutionsbevægelsen. Den 8. november blev republikken således erklæret i München.

Noske fulgte nøje den lokale udvikling rundt omkring i Slesvig-Holsten, og hvor der var klager over soldaternes optræden, lykkedes det ham med stort held at skride ind. Et medlem af soldaterrådet i Flensborg skrev kort efter sine indtryk af Noske, da repræsentanter for arbejder- og soldaterrådet den 9. november havde været $i$ Kiel for at få nærmere anvisninger: "Han gjorde på mig indtryk af at være et menneske med voldsmentalitet.... Stor, kraftigt bygget og mørkskægget er han en ikke uinteressant fremtoning. Det første, han sagde til os, var følgende: "Nu er I vel klar over, at I allesammen er mytterister og burde være skudt, om loven var sket fyldest. Det siger jeg jer, aflønning og forplejning fortsætter, så længe I ikke laver nogle svinerier. Forekommer sådan noget, vil jeg hensynsløst afskære jer fra enhver tilførsel «. ${ }^{3}$

Hvad kunne republikken Als vente sig, hvis den altså fandtes?

\section{Revolutionsdagene i Sønderborg}

\section{Udsagn fra Noske, Topff og hans fjender}

Det ville være dejligt, om Noske selv havde skrevet noget om revolutionen i Sønderborg, og det har han faktisk, hvilket Kaj Nissen ikke var opmærksom på, da han helt afskaffede republikken Als. I 1920 udkom Noskes erindringsbog »Von Kiel bis Kapp. Zur Geschichte der deutschen Revolution«. Det hedder heri om begivenhederne på Als:

»En mand, der drev sit uvæsen på Als, lod jeg to gange bringe på lazarettet, da han som følge af mangel på søvn var blevet helt utilregnelig. Han stak hver gang af igen. Tredje gang lod jeg ham føre frem for mig af bevæbnede og så spærre inde $\mathrm{i}$ arrest. Undersøgelsen bragte ikke for dagen, at han havde forøvet alvorlige strafbare handlinger. At han ville regere øen Als alene (min fremhævelse) var kun et udslag af forbigående forrykthed. Krigsretsråden foreslog mig at frigive ham, hans kone var kommet for at tage ham med hjem. Den følgende dag mødte han i skinnende ren uniform hos mig og erklærede: »Hr. guvernøren har spærret mig inde. Det betakker jeg mig for. Nu er jeg igen fuldstændig fornuftig«. Et år senere har jeg fået et nydeligt brev fra ham. - Ved andre vilde mænd var det tilstrækkeligt, at jeg lod dem føre for mig og truede dem med indespærring for at få dem til at blive manerlige «.

Det er klart, at Noskes udsagn må være en vigtig kilde. Det er ned- 
skrevet kort efter begivenhederne, og Noske har selv truffet Topff. I det følgende skal vi se, hvordan det samtidige kildemateriale harmonerer med Noskes korte omtale. Først skal der dog gives et kort overblik over begivenhederne.

Bruno Gustav Eugen Topff var skrædder og født i Potsdam den 2. november 1886 . Om hans liv inden revolutionen er der til dato ikke fundet nogle oplysninger, f.eks. om han skulle have været politisk aktiv. Under krigen var han overskræddergast i marinen, altså håndværker. Da revolutionsbudskabet nåede til Sønderborg, var han indlagt på marinelazarettet. Han led af tuberkulose. Imidlertid formåede han at sætte sig i spidsen, da soldaterrådet blev valgt ved et møde af marinesoldater og også nogle fra hæren på en eksercerplads ved marinestationen den 6. november om eftermiddagen. Officerer og embedsmænd i byen måtte affinde sig med den nye tilstand, og den tyske avis Sonderburger Zeitung blev stillet under soldaterrådets censur, men indeholder i øvrigt kun lidt stof om revolutionen. Der tales ikke om nogen republik Als i den, og den omtales heller ikke i nogen af de proklamationer, der kendes fra soldaterrådet. Byens arbejdere kom ikke med i bevægelsen med dannelse af et arbejderråd, før Topff om formiddagen den 9. november på et nyt møde havde meddelt, at han trak sig tilbage af helbredsgrunde. ${ }^{5}$

Topff har i et læserbrev til Sonderburger Zeitung den 20. marts 1919 forsvaret sin rolle under revolutionen; men han forblev ikke uimodsagt. I det følgende gengives dette læserbrev i sin helhed i oversættelse. $^{6}$

Højtærede hr. redaktør.

Sønderborg den 20. marts 1919.

Da jeg i den sidste tid gentagende gange fra politiets side er blevet undersøgt for våben o.s.v., og der ovenikøbet fandt gennemsøgning sted i de af mig beboede værelser, beder jeg Dem om venligst at lade følgende linjer optage i Deres avis. Idet jeg takker Dem hjerteligt på forhånd, forbliver jeg med største højagtelse

Bruno Topff.

Da jeg som anstændigt menneske ikke stiller mig på samme trin som angivere, så har jeg indtil nu ikke anset det for nødvendigt at vende mig mod så karakterløse bagvaskere. Men nu må jeg gøre det, for når den slags folk ikke undser sig for at mistænkeliggøre mig over for myndighederne, så kaster det er dårligt lys på mig, hvis jeg ikke værger mig 
derimod. Disse folk af lumpent sindelag vil jeg nu sige, at jeg er fuldstændig partiløs. Jeg beklager, når jeg tænker på, hvilke tilstande der hersker i revolutionens følge. ${ }^{7} \mathrm{Jeg}$ har i sin tid handlet som idealist, ene og alene som sådan overtog jeg ledelsen af 4-5000 mand. Set fra én side: Da vort fædreland dengang den 9. (der må menes den 6.) november $\mathrm{i}$ dette frygtelige kaos truede med at forfalde til anarki, da var jeg én af dem, der først havde mod til at lægge tøjler på en løssluppen og delvis tøjlesløs masse. Her i Sønderborg gjorde jeg det helt alene. Jeg erkendte dengang straks tingenes tilstand, og min bestræbelse var blot at forhindre blodsudgydelse, røveri og plyndring. Hvem ved da, med hvilke forlangender de mellem os værende udannede elementer, og det var ikke få, er kommet til mig? Hvem ved da, hvor meget jeg har forhindret $\mathrm{i}$ al stilhed? Hvem har da set, hvordan jeg her måtte dæmpe og dér måtte skræmme med en tordentale, her for at forhindre voldsgerninger, dér for at fastslå min autoritet. Der er overordentlig mange, som $i$ dag er forpligtet til at takke mig, for en løssluppen masse er i stand til alt. Jeg har kun arbejdet henimod at opnå og bevare en enighed mellem hær og marine. For enhver må forestille sig den fare, som bestod, hvis det var kommet til et sammenstød mellem de to parter. Døde ville der have været og i følge hermed plyndring. Jeg har, og det vil alle officerer bekræfte mig, hele tiden sagt, at man ikke måtte lade nogen officer bøde for et system, og truet med strenge straffe for det tilfælde, at én eller anden tillod sig at lade sin vrede gå ud over nogen ved denne gunstige lejlighed. Og der var mange, som gerne havde gjort det!!! For alt det, som jeg gjorde, har jeg ikke fået nogen tak. Jeg har på karakterløse slynglers tilskyndelse måttet lade mig prøve på hjerte og nyrer i tre uger i varetægtsarrest. Og havde man blot fundet en døjt, der talte imod mig, så havde man drejet halsen om på mig. Men jeg er kommet ud af denne affære som hædersmand. Resultatet af revolutionen er for mig blot, at jeg fuldstændig har undergravet mit i sig selv svage helbred, har sat omtrent 2000 mark til og må beklage tabet af mine ting til en værdi af 600 mark. Og nu kaster man snavs efter mig på den nedrigeste måde? Hvorfor har de folk ikke mod til at sige: "Det er mig, som rejser denne mistanke!« Aldrig ville det være faldet mig ind at træde frem for offentligheden, jeg ønsker ikke, at man siger, at jeg fører mig frem for at prale. Jeg ønsker fred, den har jeg brug for. Det må jeg lægge bagtalerne på sinde. Jeg beklager det dybt at have rakt min hånd til at lede bevægelsen i de første dage i Sønderborg. Vedlagt kan de folk, som skulle have lyst til fortsat at beære mig med deres sinteresse $\lll$, stedse holde sig medfølgende retskendelse for øje: 
I. Marine-Inspektions Ret

\section{Bekræftet afskrift Kiel, den 4. januar 1919.}

1.) Sagen mod overskræddergast Bruno Topff K.5. I. W.D. indstilles, fordi der efter resultatet af undersøgelsen ikke længere består mistanke imod ham om en strafbar handling.

2.) $\mathrm{pp}$.

3.) $\mathrm{pp}$.

Dommeren

sign. Sievers

Marinekrigsretsråd sign. Becker

Dette ordrige læsebrev er ikke særlig oplysende for den, der søger oplysninger om, hvad der egentlig skete i revolutionsdagene. Men interessant er det at se, at Topff fremstiller sig selv som en mådeholdets mand, der af ren idealisme satte sig i spidsen for revolutionen for at forhindre den $i$ at udarte. Kammeraterne reduceres til tøjlesløse masser. Så vidt man ellers kan slutte af brevet, må politiets opmærksomhed have skræmt ham, så det nu er magtpåliggende for ham at tage afstand fra de revolutionære bevægelser, hvis bekæmpelse i Tyskland nærmede sig sit højdepunkt på denne tid.

Da Topff nu på denne måde havde henledt offentlighedens opmærksomhed på sig selv, protesterede en anden overskræddergast mod denne fremstilling. I et langt læserbrev løftes sløret for, hvordan de mange bagvaskere opfattede Topffs rolle. Det vigtigste af Philipp Weigleins læserbrev af 3. april 1919 skal citeres eller refereres i det følgende. ${ }^{8}$

Weiglein skriver indledningsvis: "Det havde afgjort været bedre for hr. Topff, om han havde givet sin artikel en anden form eller helt tiet stille for at vaske sig ren over for den brede offentlighed; eller ville han blot som tidligere »diktator« i Sønderborg bringe sig i beklagelig erindring for et herboende publikum?

Men nu til sagen, hvor jeg gerne i første række vil bemærke, at jeg som helt upartisk griber pennen for at retfærdiggøre det utal af tidligere kammerater i marinen, som hr. Topff på meningsløs, brutal måde har fornærmet og bagvasket på det dybeste«. Weiglein mener, at politiet interesserer sig for Topff, fordi han for nogle uger siden skal have sagt til en bekendt: "Jeg har 40 mand, som jeg kan stole på, sørg for, at du skaffer lige så mange, så er spillet vundet «! Topffs omdømme efter revolutionen var åbenbart sådan, at nogle troede ham i stand til at iværksætte et nyt revolutionsforsøg. 
Weiglein fortsætter: „Når De tager en beklagendes hykleriske maske på og henviser til de tilstande, som revolutionen har haft til følge, glem så venligst ikke hr. Topff, at det netop var Dem og ingen anden, der dengang i november $1918 \mathrm{kom}$ ned fra marinelazarettet og nede ved Marineskolen stod op på en stige og oppiskede og opirrede masserne og helt drabeligt udskældte Sønderborg-garnisonens officerer. Netop Dem, der i dag skamroser officerene, Dem var det, der dengang, stående på stigen, sagde: "Kammerater, nu har $\mathrm{i}$ magten $\mathrm{i}$ jeres hånd; jeres officerer har ikke mere at sige over jer. Tyranniet er slut! Vi er frie mænd og behøver ikke længere at lade os trække rundt ved næsen af den slags folk. Der er da nogle imellem, som var retfærdige, men de fleste har opført sig svinsk, og de havde fortjent - at man stillede dem op af muren og knaldede dem ned. - Men vi vil lade nåde gå for ret og lade dem løbe, så vi viser dem, at vi ikke er barbarer«. - I forbindelse dermed bemærkede De dog, at den daværende stabslæge i lazarettet også havde behandlet folkene "svinsk «!...

$\mathrm{Og}$ når hr. Topff fordrister sig til at tale om udannede elementer, ja, så har han da glemt, at der dengang mellem de 500 fyrbødere var mangen ung dreng, som - ophidset af hr. Topff - pludselig tænkte: »Nu er jeg herre, og intet menneske kan eller må sige noget over mig! $\mathrm{Ja}$, først manede jeg ånderne frem, og så kan jeg ikke mere slippe fri for dem!

Hvad foreningen af hæren og marinen angår, så har det overhovedet ikke noget med den daværende ro i Sønderborg at gøre, hovedbestræbelsen for hr. Topff sammen med hans fanatiske medhjælper »Lyri« var i første række rettet mod, at kammeraterne fra hæren ikke faldt marinen i ryggen!

Og hr. Topff bryster sig af, at han helt alene har holdt den tøjlesløse masse i skak. O, hr. Topff, De glemmer fuldstændig, at det ikke kan bestrides, at hele Krigsmarineskolens mandskabskompagni med deres officerer, først og fremmest med hr. fregatkaptajn Reichardt i spidsen, allerede inden De stod op på stigen, havde ordnet hele sagen i største ro og orden. Vi havde allerede vore tillidsfolk, og aflønningen, mavespørgsmålet (forplejningen), orloven, tjenesten - alt var ordnet, og hvad ville De dog mer? Alt var der allerede! ... Men Dem plagede storhedsvanviddet, og havde De også gjort det i lazarettet således som vi, så havde hele sagen været klar; men De skulle først have den store, af Deres taler oppiskede, tøjlesløse masse for at opnå noget! Altså fra vores side skal De ikke vente nogen tak!

Hvorfor De var tre uger i varetægtsfængsel, ved De vel bedre end jeg. 


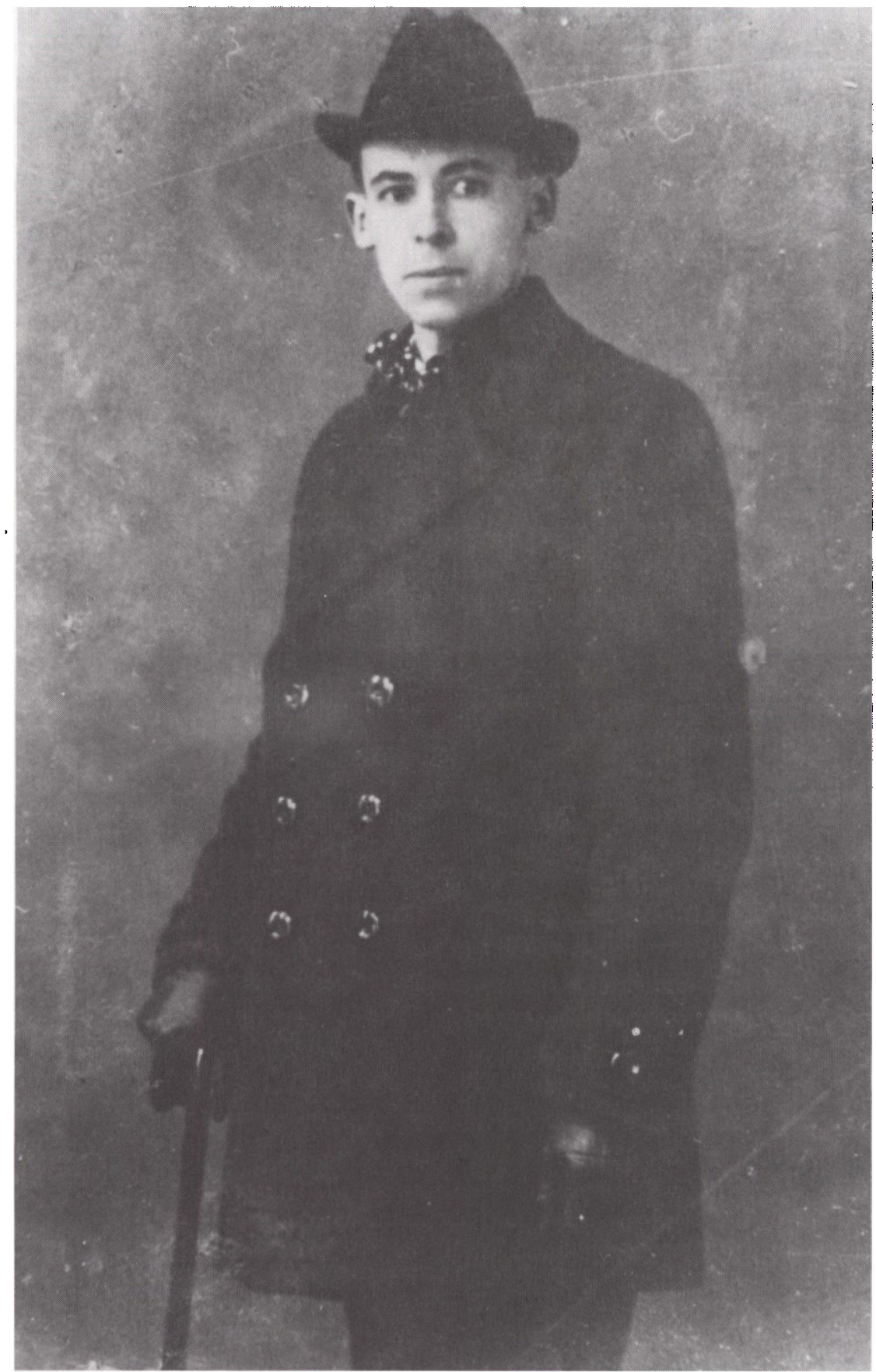



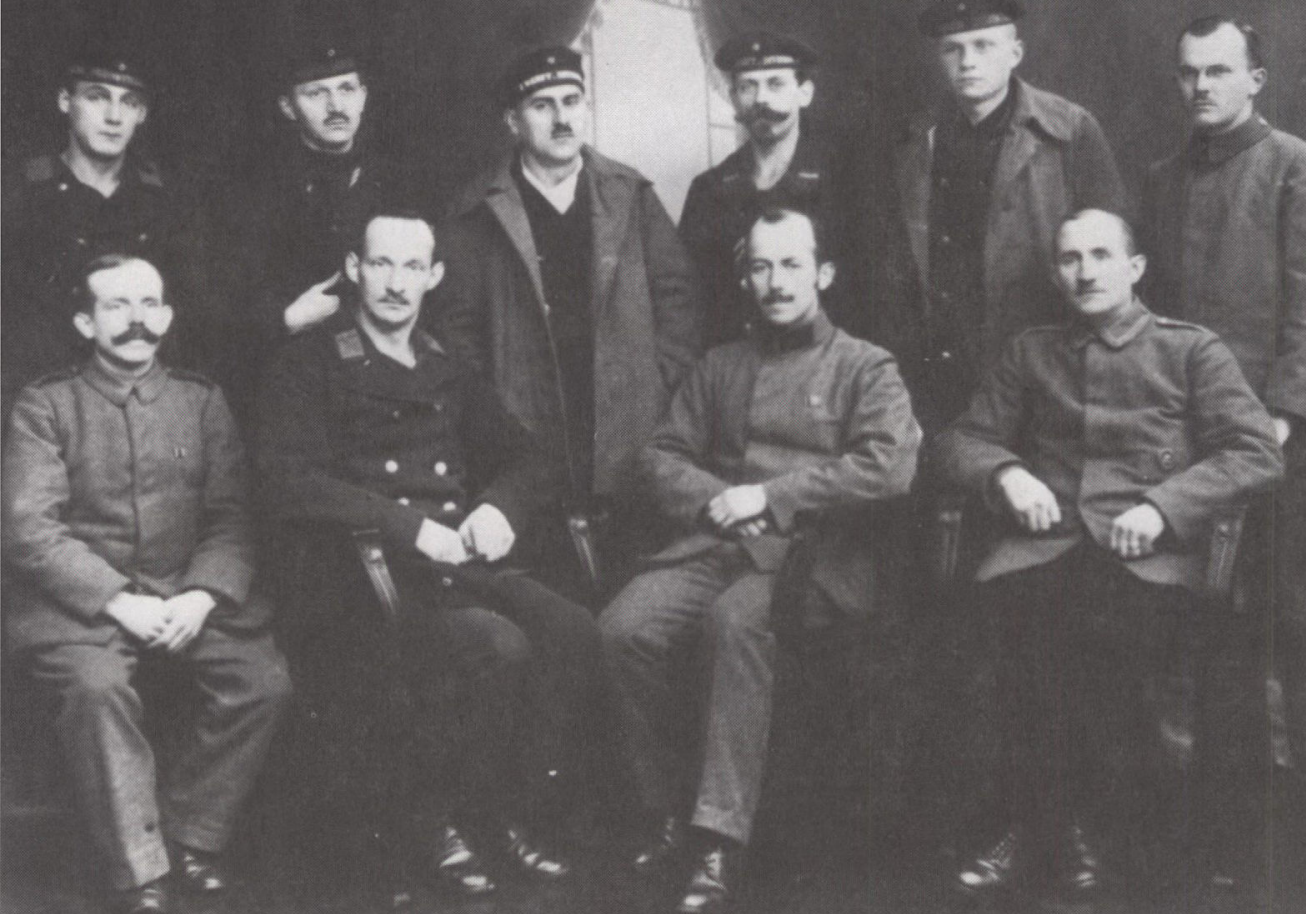

Efter Topffs afgang aflestes énmandsstyret af et normalt soldaterråd, der udvidedes med fem mand. F\& dage efter dannedes arbejderrådet $i$ Sonderborg, og rådssystemet fungerede nu på samme måde som $i$ den ovrige provins. Billedet viser forretningsudvalget for arbejderog soldaterrådet $i$ Sonderborg. På nederste rakke yderst til venstre ses byens socialdemokratiske arbejderleder $i$ overgangstiden, murer Richard Hempel. (Museet pd Sonderborg Slot)

Men hvorfor smider De sådan om Dem med udtrykket »slyngler«? Det behøver De slet ikke, eller har De også glemt, at De dengang stående på vognen i Marinekasernens gård efter en tale har erklæret: „Så kammerater, nu tager jeg andet kluns på og kører med en bil over den danske grænse for at forhandle med regeringen dér - så Als bliver dansk!« Og så fordrister De Dem alligevel til at lade sådanne tirader løbe af stabelen i en god tysk avis og smide lort på anstændige folk?!«

Bruno Topff (1886-1920), lederen af revolutionen i Sonderborg den 6.-9. november 1918. Hans egenrådighed $i$ revolutionsdagene, der senere erkendtes af ham selv, har formentlig skabt grundlaget for historierne om "republikken Als" og dens "prasident" Topff. Men hvordan han helt pracist har opfattet sin rolle i de fä dage, han var ved magten, og hvad han har sagt til folk $i$ sin stadig mere uligevagtige tilstand, kan nappe opklares $i$ dag. (Museet pd Sonderborg Slot) 
Dernæst anklager Weiglein Topff for at have ladet den daværende revolutionskasserer Hansen udbetale 1000 mark til en ven fra Berlin. De skulle bruges til at fremme revolutionen i Berlin. Samtidig minder Weiglein om, at Topff lod foranstalte salg i marineskolen af en række beklædningsgenstande, der umuligt kunne være hans egne allesammen. Weigleins indlæg slutter bl.a. med følgende ord: "Jeg tror, at De oprigtigt beklager, at De pludselig blev så syg, at De ikke mere var i stand til at lede alt. Men ethvert fornuftigt menneske, enhver borger $i$ Sønderborg, kan prise sig lykkelig for, at det var sådan, for hvem ved, hvad der ellers ville være sket. Glem ikke hr. Topff, at den, der bor i et glashus, ikke bør kaste med sten!ณ....

Topff svarer igen med et læserbrev dateret den 7. april 1919. Han mener ikke, at Weiglein er intelligent nok til at have skrevet brevet selv. Anklagerne affærdiges med, at de anførte ting står ordret i hans retsakter, og han er som tidligere nævnt blevet frikendt. For at bekræfte sin uskyld aftrykker han nu to breve, ét fra Noske og ét fra Marineinspektionens domstol, hvori Topff meddeles tilladelse til at holde orlov $\mathrm{i}$ Slesvig i julen 1918.

Weiglein svarede kort herpå, bl.a. følgende:

"Ved min redegørelse af den 4. dennes ville jeg kun forsvare mine kammerater, som var rejst, desto mere som det er gammel skik at forsvare fraværende, henholdsvis ikke at angribe dem. Desuden er min redegørelse ikke blevet gendrevet. Til Deres beroligelse hr. Topff, meddeler jeg Dem, at jeg alene var forfatter til artiklen, og dermed betragter jeg denne sag som afsluttet for mit vedkommende. De kunne jo ikke forsvare Dem!"...?

Hermed erklærede Sonderburger Zeitung diskussionen for afsluttet. Den gengives så udførligt her, fordi den er det hidtil eneste fundne eksempel på en diskussion med Topff om sagen. Han er forståeligt ivrig for at nøjes med at henvise til frifindelsesdommen. Desværre kan vi ikke af det her gengivne se præcist, hvad det egentlig var, Topff blev anklaget for, og hvad straffen ville være. Men vi forstår, at anklageskriftet har indeholdt de samme elementer som Weigleins læserbrev. Af Noskes erindringer fremgår dog, at frifindelsen ikke var udtryk for, at man fandt Topff helt sagesløs, men primært ikke har anset ham for tilregnelig i revolutionsdagene. Det var ikke umagen værd at gøre mere ved sagen.

Weigleins anklager kan ikke bekræftes ad anden vej; men vi tager dem som et udtryk for en stærk uvilje mod Topff blandt mange af hans kammerater, særlig i hæren. Der har åbenbart været et stærkt modsæt- 
ningsforhold her. De interne forhold i soldaterrådet har vi intet kildemateriale om ellers. I det følgende vil vi se på, hvad der egentlig kan siges om Topffs gerninger i novemberdagene, og det vil næsten udelukkende være, hvad civilbefolkningen oplevede.

\section{Begivenhederne i Sønderborg}

Der findes meget erindringsstof om begivenhederne $\mathrm{i}$ revolutionsdagene i Sønderborg; men det er for størstedelen fremkommet meget længe efter begivenhederne og præges ikke af den store pålidelighed. Robert Huhle beskæftiger sig indgående og kritisk med en del af disse sene erindringer, der ikke skal refereres nærmere her. I det følgende er det hovedsagelig Ernst Christensens allerede omtalte erindringer fra 1928 , der vil blive brugt, samt andet samtidigt stof fra revolutionsdagene eller kort derefter.

Proklameringen af revolutionen og det formentlig ret uorganiserede valg af soldaterrådet var et internt militært anliggende som allerede skildret i Weigleins læserbrev. A. Thyssens skildring fra 1966 af Topffs magtovertagelse rummer lighedspunkter med Weigleins, nemlig at Topff holdt en tordentale med angreb på officererne. Officererne måtte lægge deres sabler for fødderne af Topff, »noget, der selvfølgelig gjorde et stærkt indtryk på os unge, og sikkert må have været den bitreste stund i en tysk søofficers liv«. For at kunne færdes frit var det derefter nødvendigt at færdes uden militære værdighedstegn, og med noget rødt på uniformen for at vise, man var loyal mod omvæltningen. ${ }^{10}$

Gårdejer Ernst Christensen, Asserballe, fortæller sine indtryk fra Sønderborg den 7. november: "Alle militære gik uden sidevåben og uden kokarde. $\mathrm{Og}$ de så forresten ikke så kede ud. Ja, der gik et par officerer og så lidt mellemfornøjede ud, men det var vel nærmest, fordi det var deres forhen underordnede, der havde revet kokarderne af dem, det var såmænd ikke, fordi krigen var forbi - det var de fleste officerer vist ligeså glade for som de andre militære«.

Samme dag kunne Sonderburger Zeitung bringe en kort meddelelse om revolutionen i spalten med lokalnyheder. Efter at have nævnt soldaterrådets dannelse den 6. november hedder det: " Som borgmester Dr. Petersen meddelte i et $i$ går aftens afholdt hastemøde for bykollegierne, har soldaterrådet overtaget den offentlige myndighed i byen og garanteret ordenens opretholdelse. Roen er ikke på nogen måde blevet forstyrret. Marinevagtposter med hvidt armbind har bl.a. besat banegården, brovagten og posthuset. Der patruljeres i gaderne. Man så også 
nogle automobiler, som førte et rødt flag og med marinemandskab i, køre af sted. De civile myndigheder hindres ikke i deres virksomhed. I indforståelse med soldaterrådet vil de sørge for forplejningsanliggender; der er også straks udstedt et forbud mod udskænkning af spiritus og afholdelse af danseforlystelser og koncerter«. Også landråd Schönberg må være blevet orienteret om soldaterrådets oprettelse samme dag. Hans private automobil blev nemlig rekvireret og flittigt benyttet af soldaterrådet i de følgende dage. Senere måtte arbejder- og soldaterrådet dog udbetale ham erstatning for brugen. ${ }^{12}$

Revolutionen forløb altså ret fredeligt i Sønderborg, og det gjorde den også i Nordslesvig i øvrigt, lige som situationen i revolutionens arnested Kiel hurtigt var ledet ind $i$ rolige baner. Grundene hertil skal vel søges dels i de gamle militære og civile magthaveres forbløffende hurtige kapitulation i situationen, dels i soldaterbevægelsens blandede karakter. Krigstrætheden var drivkraften i den, og langt fra alle deltagere havde visioner om at ændre samfundet med det gode eller det onde. Når Topff i sit tidligere citerede læserbrev tager æren for, at revolutionen forløb fredeligt i Sønderborg uden blodsudgydelse og plyndringer, må man sige, at det var også at forvente på baggrund af forløbet andre steder. Hvorfor skulle soldaterne i Sønderborg vise sig mere tøjlesløse end dem i Haderslev, Åbenrå og Flensborg f.eks.? De »tøjlesløse masser« er snarere et produkt af Topffs fantasi, og nerverne stod naturligvis på højkant hos mange i de første revolutionsdage, eller også er de opfundet for tilfældet, da Topff i foråret 1919 følte sig tvunget af politiets opmærksomhed til at fremstille sig selv som fredens mand under revolutionen.

Imidlertid er der flere særtræk i udviklingen i Sønderborg, når man sammenligner med det øvrige Nordslesvig, og de kan nok hovedsagelig tilskrives Topff. Inddragelsen af landrådens privatautomobil er allerede omtalt. Et andet træk er, at Sonderburger Zeitung den 8. november kunne meddele, at dens videre udgivelse var stillet under soldaterrådets censur. Efter Topffs afgang fortælles de nærmere omstændigheder i avisen den 11. november. "Først blev der af soldaterrådets leder, Topff, torsdag aften (d.v.s. den 7.) udstedt forbud mod at udkomme igen, fordi fyrst Bülows artikel om kejserspørgsmålet var blevet aftrykt efter Norddeutsche Allgemeine Zeitung. Dette blev, da vor redaktion klagede derover, fredag formiddag indskrænket til dekretering af forcensur. Fredag aften blev det derpå af soldaterrådets leder under trussel om magtanvendelse (lukning af avisen og beslaglæggelse af trykkeriet til soldaterrådets formål) forlangt af ledelsen, at avisen betingelses- 
løst skulle udleveres til ham, eller redaktionen skulle fuldstændig stille sig i den nyeste bevægelses tjeneste. Ved hr. landråd Schönbergs venlige bistand blev der sluttelig set bort fra den hermed påtænkte samvittighedstvang, som redaktionen naturligvis ikke kunne underkaste sig, og det blev ved udøvelsen af forcensur. Denne er nu også ophævet, som det blev os meddelt i dag til middag«. Det bør nævnes, at pressefriheden var et krav, oprørsbevægelsen i Kiel havde stillet allerede den 4. november. ${ }^{13}$

Topff havde ellers også henvendt sig til befolkningen med proklamationer i flyvebladsform. Tre flyveblade kendes i dag, hvoraf de to også er trykt som bekendtgørelser i Sonderburger Zeitung den 8 . november. Der er også nogle særprægede omstændigheder omkring flyvebladene, der derfor skal omtales nærmere her og i øvrigt gengives i deres helhed som illustrationer. Man kan indledningsvis mærke sig, at der ikke i nogen af dem tales om en republik Als.

Fra sit møde med Topff den 7. november fortæller Ernst Christensen følgende træk vedrørende tilblivelsen af proklamationerne. "... interessant var det også, da der kom en flyver ind, hvis maskine vi lige havde hørt komme, og som var gået ned på vandet udfor marinestationen. Han kom med nogle store plakater fra Noske i Kiel, hvori der opfordredes til at opretholde ordenen i befolkningen o.s.v. Topff løb dem igennem, slog en tyk streg over Noskes navn og skrev Topff i stedet, smed dem til en marinesoldat med befaling om hurtigt at få dem trykt i Sonderburger Zeitungs hurtigpresse, ${ }^{\circ} \circ \mathrm{g}$ i løbet af 1 time må de være ophængt på iøjnefaldende steder $\mathrm{i}$ byen «..14

Pålideligheden af Ernst Christensens. iagttagelse bekræftes af, at Noskes flyveblad (dateret 5 . november) er bevaret og også her gengives som illustration. Vi kan derfor se, hvad det var Topff ændrede. Flyvebladet »Beschlüsse des Soldatenrates« var både stilet til soldaterne og til civilbefolkningen i Kiel. Soldaterrådet i Sønderborg har formentlig mere modtaget det til orientering og ikke til ordret offentliggørelse uden tilpasning til de lokale forhold.'Der tales i opråbet f.eks. om det sstore soldaterråd «. Det var et organ, der oprettedes i Kiel, og altså ikke fandtes i Sønderborg. Der tales også om, at den militære sikkerhedstjeneste i Østersøen vil blive opretholdt. Også dette var primært en sag for Marinestation der Ostsee.

Fra Noskes opråb mangler imidlertid sætningen om, at man skal afholde sig fra ethvert formålsløst skyderi. Man kan kun gætte om grunden til denne udeladelse. Er sætningen strøget i erkendelse af, at der i forvejen overhovedet ikke var blevet skudt i Sønderborg, er det 


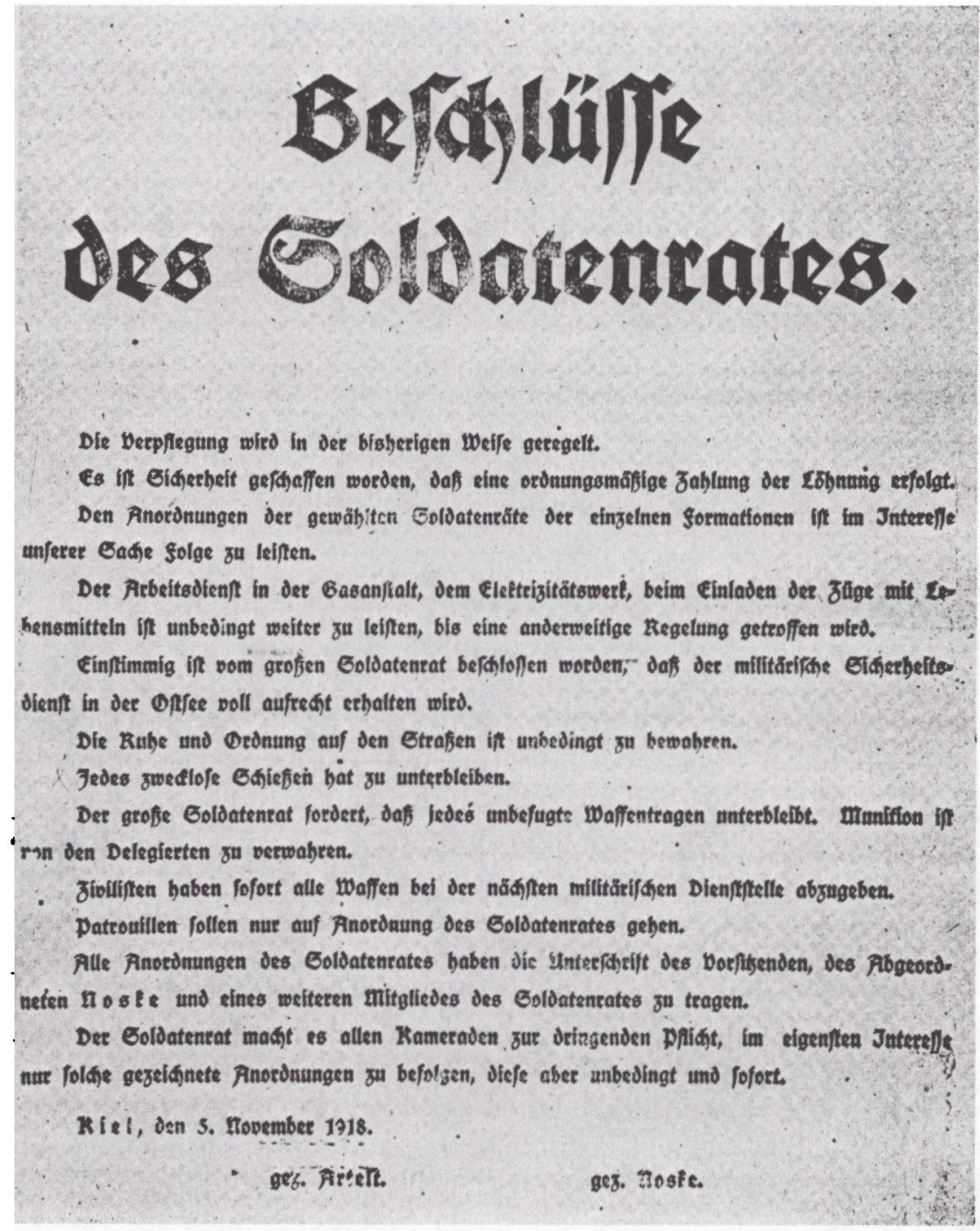

Et af de forste opråb, som blev udsendt af soldaterrådet $i$ Kiel, efter at Gustav Noske havde fået kontrol over begivenhederne. Det blev med små andringer overtaget af Bruno Topff $i$ Sonderborg. (Efter Dirk Dähnhardt: Revolution $i$ Kiel)

sket ved en fejl i trykkeriet o.s.v? Om der skal lægges nogen særlig betydning $\mathrm{i}$ dette forhold, er næppe til at sige $\mathrm{i}$ dag.

En anden ændring i Topffs opråb drejer sig om underskriftsspørgsmålet. I opråbet fra Kiel hedder det, at alle rådets anordninger skal 


\section{Beichliiife Dez Ðpldatemrntes.}

Die Berplegung wito in Der biskerigen T3elie aeregelt.

(5iz tit Eiduethelt ge'chaffin worben, hab cine oronungsmäblge Bablung ber Q3bnung erfolgt.

Den Unorinunacn ber geroäblten Eolbatentäte bex eimzlnon forinationen ift tm Interelfe unferer Gahe ઉolg: au leiften.

Der Arbeitżbienit in ber Gasanitalt. betm Geftristtät3merf, beim Einlaben Der Buae mit Rebengm!tteln iit unbe* bingt weiter au leiften, bis eine anber meitige Regelung getruffen mird.

Ginitimints ift vom groger Solhaten. rat bejulloffen morden, onf ber milltäri=

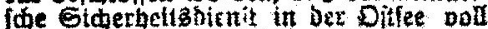
aufredt erbalten wits.

Die pube und Oronumg auf ben Etrasen ift unbebingt au beroohen

Der atofe Enloalenrat forbert. bab jebes unbefugte 2 if fientrcgen unter bletbt. munition if gon orn Delegierten au permabren.

Blottlften baben lotort alle \$offen bet ber nảdilem mititätichen $D$ :enititelle ab ougeber.

ibatzouliten follen nut aul Anorbnura bes Eolbatenrats geber

Eämtlthe Qunorbnumgen be Solbaton" rate baber bie llnteríbrifit bes Bor $^{2}$ fibenten bes Golbaitenrats ou traaen.

Der Eolbaten rat mant es allen Same: raben nur bringendan uffidit, in etgenften Intereffe nur folde geseitinete Hnorb. nungen au befolgen, bieje aber unbebingt und fofort.

Eouberburg, ben 7. Roo. 1918.

Soloalentat Sonderburg. ges. Toplf.

3. Iellte fär bas geben unb Gut bex \&ürra=t volle Baxautie

\section{Bejegl bes Goldatenrates.}

(5e wirb ber Bivllbevälleruna zur \$flith gemađt. Jugenolide und Sinter vor allem oon ber Gtrabe fern au balfen.

Die Biotlbeodtterung bat nur au ben notrendigiten Beforgumgen bie Etrafe su betreter.

Im Interefle ser Bivilbevölferung ift es erforberltch, afiez au vermelben, was berfilben jum gindtell aereiden lann.

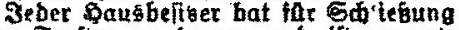
bex Zeniter a forgen unt if verant. mottlich fär eventuelles Gabiefen.

3uwbexhaubluagen mexben ftreng behraft.

Dex Eoldatentat.

To af Bruno Topffs proklamationer, gengivet efter Sonderburger Zeitung den 8. november 1918. De udsendtes også som flyveblade, og også det lille opråb bar dér Bruno Topffs signatur.

være forsynet med underskrift af formanden og ét rådsmedlem mere, og det blev i det hele taget det normale for rådene, at deres proklamationer bar flere underskrifter $i$ overensstemmelse med rådsideens demokratisk-kollektive ånd. I Sønderborgopråbet står der imidlertid, at 


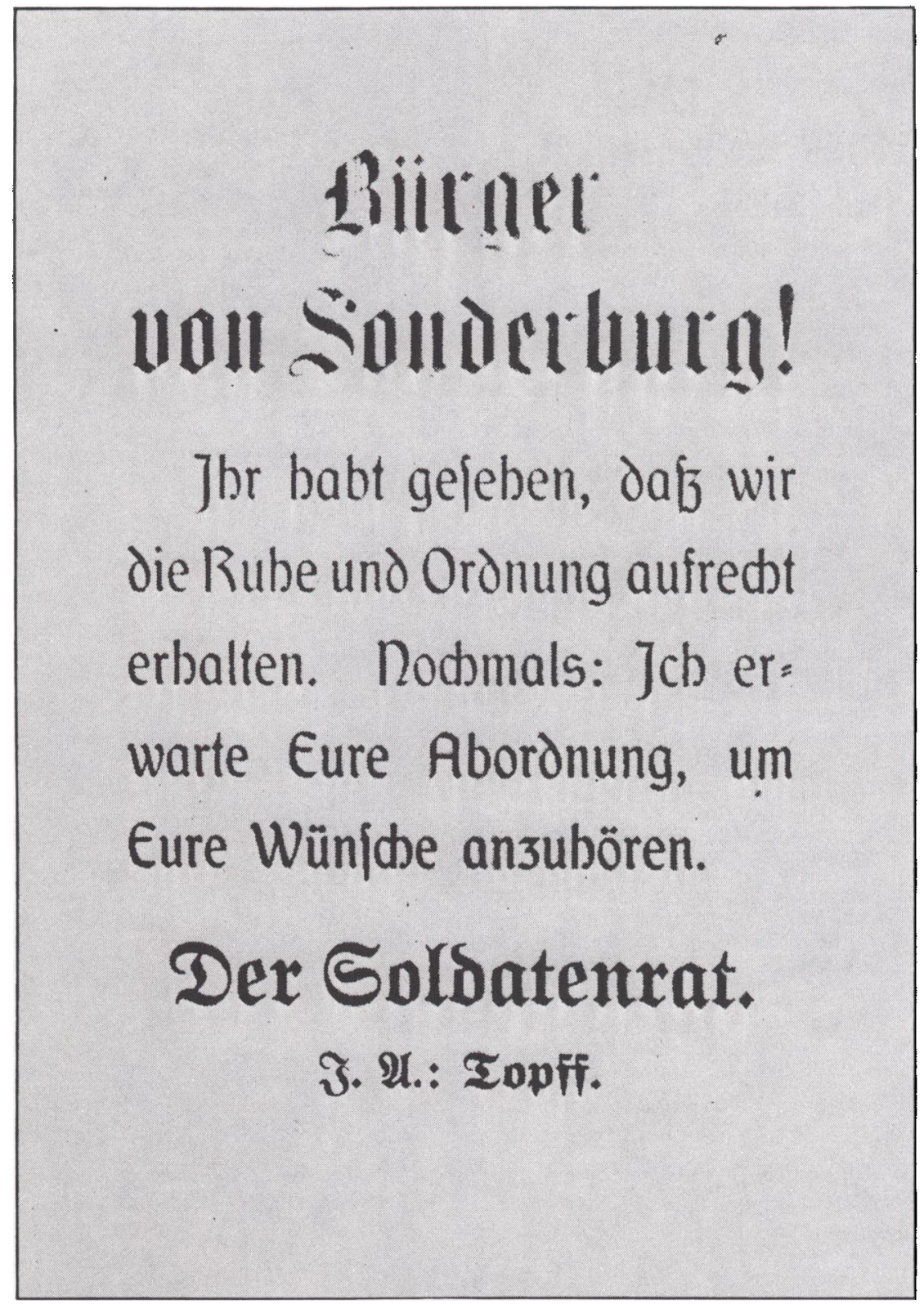

Det tredje oprab, der kendes fra Topff. I modsatning til de to foregående synes det at vare skrevet af ham selv. Heri opfordrer han borgerne til at sende en deputation og forebringe deres onsker. 
soldaterrådets anordninger kun skal bære formandens underskrift, d.v.s. Topffs. Efter opråbet har Topff tilføjet følgende sætning »Ich leiste für das Leben und Gut der Bürger volle Garantie«, Topff garanterer for borgernes liv og ejendom. Et mindre opråb blev samtidig trykt i Sonderburger Zeitung den 8. november. Det var også udsendt som flyveblad og bar her Topffs navn ligesom det længere opråb, der lige er omtalt. Formentlig er det lille opråb »Befehl des Soldatenrates« også importeret. Indholdet svarer i hvert fald dårligt til forholdene i Sønderborg. Civilbefolkningen skal så vidt muligt holde sig borte fra gaderne, og husejerne gøres ansvarlig for eventuelt skyderi ud af vinduerne! Hvem er det Topff har forestillet sig skulle skyde på hvem?

Den tredje proklamation, der kendes fra Topff, synes han derimod selv at have skrevet. Den er stilet til Sønderborgs borgere og lyder i oversættelse: "I har set, at vi opretholder ro og orden. Endnu engang: Jeg afventer jeres delegation for at høre jeres ønsker. « Denne appel til civilbefolkningen er ikke dateret, og der er måske udstedt en lignende forud herfor, siden Topff skriver »Endnu engang « (Nochmals). Opråbet viser klart, at Topff opfatter sig som den, der også er indehaver af den øverste civile myndighed, mens rådene normalt var tilfredse med at kunne kontrollere embedsmændenes virksomhed og med, at embedsmændene erklærede sig loyale over for den nye tid. En delegation kom der nu ikke til Topff; men mange privatpersoner opsøgte ham, som det fremgår af Ernst Christensens erindringer. Også dette er et usædvanligt træk ved revolutionen i Sønderborg.

Ernst Christensen fortæller bl. a. om sine oplevelser under en audiens hos Topff: „Uafbrudt var han i virksomhed, og der var sandelig også mange ting at tage bestemmelse om, men jeg syntes rigtignok, at det for det meste var vel små ting at beskæftige sig med for en præsident." Blandt de vigtigere spørgsmål, der blev forelagt Topff, var dispensation fra forbudet mod udførsel af levnedsmidler fra øen, hvilket han afviste. ${ }^{15}$ Dette udførselsforbud er endnu et af de atypiske træk ved revolutionen i Sønderborg. Det kendes ikke fra nogen skriftlig kilde fra selve revolutionsdagene; men er bevidnet på andre måder, f.eks. i Dybbøl-Postens nekrolog over Topff, der er citeret $\mathbf{i}$ indledningen. Ernst Christensen er heller ikke i tvivl, da han skriver om Topff: „ $\mathrm{Og}$ alsingerne var han såmænd en god præsident, for udførslen fra øen var sikkert kun forbudt, fordi han undte folk noget at spise. Jeg husker, at vi på en gang fik rigeligt i spisekamret, indtil hele kortsystemet igen blev sat i gang. ${ }^{15}$

Soldaterrådene andre steder i Nordslesvig greb ikke ind i levneds- 
middelforsyningen på denne måde; men eksempler forekom længere syd på. Formodentlig har rådene regnet med at kunne styrke deres lokale popularitet på denne måde. Men indgreb i levnedsmiddelforsyningen var en meget alvorlig sag i det udhungrede Tyskland, hvor storbyerne havde brug for stadige tilførsler fra landbrugsområderne. Soldaterrådet i Sønderborg kunne forvente reaktioner herpå fra revolutionsledelsen, kan man med rimelighed antage.

Det sidste usædvanlige træk, der skal omtales ved revolutionen i Sønderborg, er Topffs interesse for pengesagerne. Bankerne blev lukket og deres ledere tvunget til at opgive, hvor store kassebeholdningerne var. Pengene blev dog ikke beslaglagt, og hvad de i givet fald skulle bruges til er uklart. Ifølge Ernst Christensen skulle dette have fundet sted den 8 . november. Dagen før havde rådet sendt et telegram til soldaterrådet i Kiel med følgende ordlyd: "Soldatenrat Sonderburg fragt an ob Soldatenrat Kiel für Soldatenrat Sonderburg einmal $100.000 \mathrm{M}$ zur Lohnungzahlung zur Verfügung stellen kann. Antwort bitte sofort.« Telegrammet er efter sin modtagelse blevet forsynet med påskriften »Eilt zum Noske vorlegen«. Hvem skulle Topff betale lønninger til? Selv har jeg tidligere nævnt muligheden af aflønning af embedsmænd, udnævnt af Topff; ${ }^{16}$ men det er formentlig mere sandsynligt, som Huhle foreslår, at der menes betalingerne til soldaterne. Hvad der er svaret fra Kiel på forespørgslen, ved vi ikke. Men efter den form, som rådsbevægelsen antog under Noskes ledelse, var det ikke soldaterrådenes opgave at aflønne soldaterne. Samme dag som telegrammet blev sendt, den 7 . november, udsendte Noske sin første guvernementsdagsbefaling, der gav klare anvisninger for forholdene på det militære område og på denne måde tilkendegav, at der nu igen var indtrådt ordnede forhold i Kiel. I dagsbefalingen hedder det om aflønningen, at den ordnes på den hidtidige måde, d.v.s. gennem de normale kanaler må meningen være. Noske fortæller selv, at det i de første revolutionsdage lykkedes at fremskaffe penge fra Berlin til lønningerne. ${ }^{17}$ Det var efter hans opfattelse naturligvis fortsat den tyske stat, der betalte soldaterne. Disse midler skulle ikke lånes af det ene soldaterråd til det andet. Sønderborgrådet har sandsynligvis fået det svar, at hvis det fulgte Noskes anvisninger, skulle han nok sørge for, at aflønningen blev foretaget som normalt. Telegrammet kan måske $\mathrm{i}$ Kiel have henledt opmærksomheden på, at forholdene i Sønderborg krævede nærmere undersøgelse.

Dagen efter, nemlig den 8. november, sendte soldaterrådet i Árøsund et telegram til Noske, hvori der bl.a. blev spurgt, om soldaterrådet 


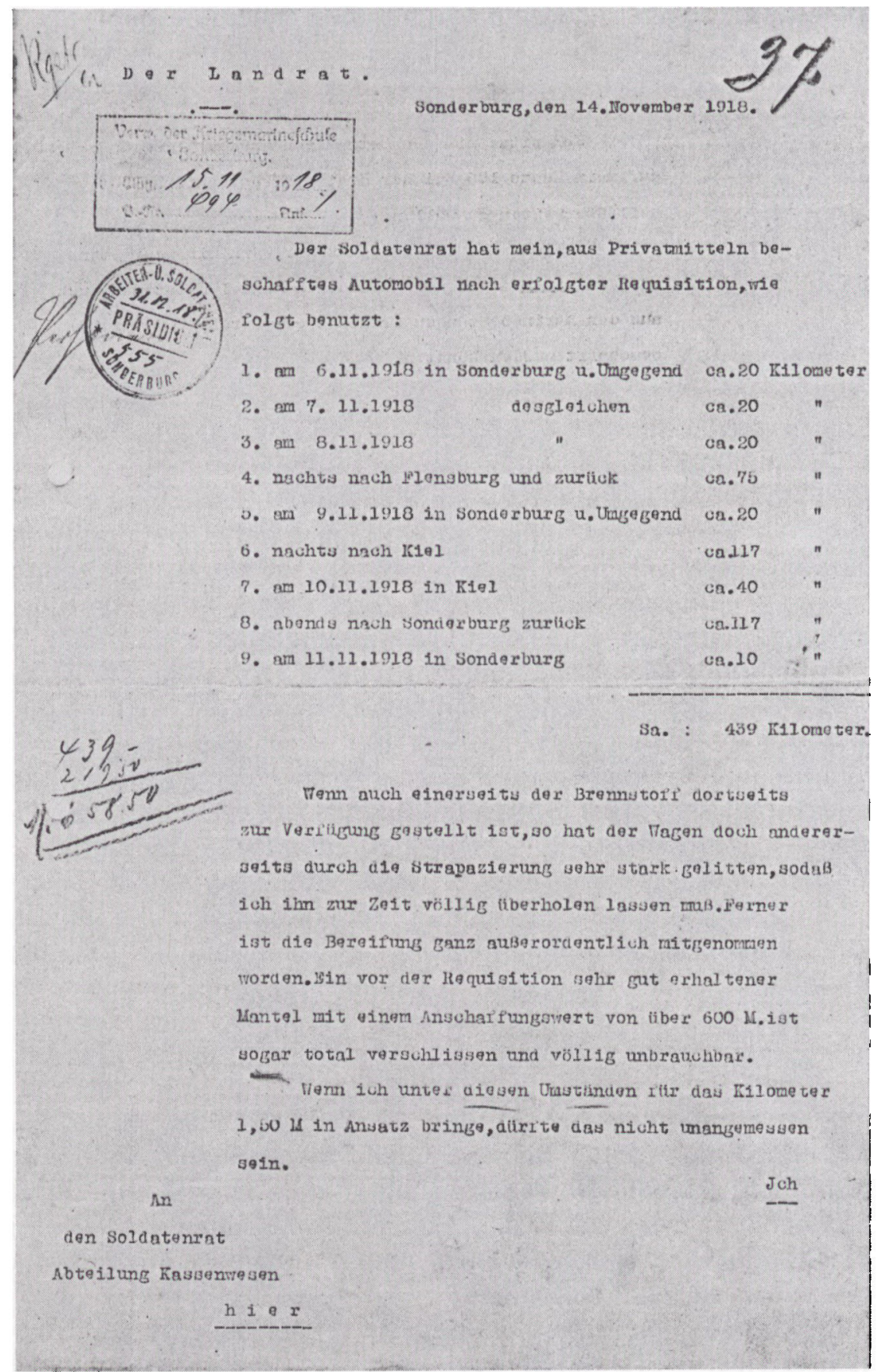




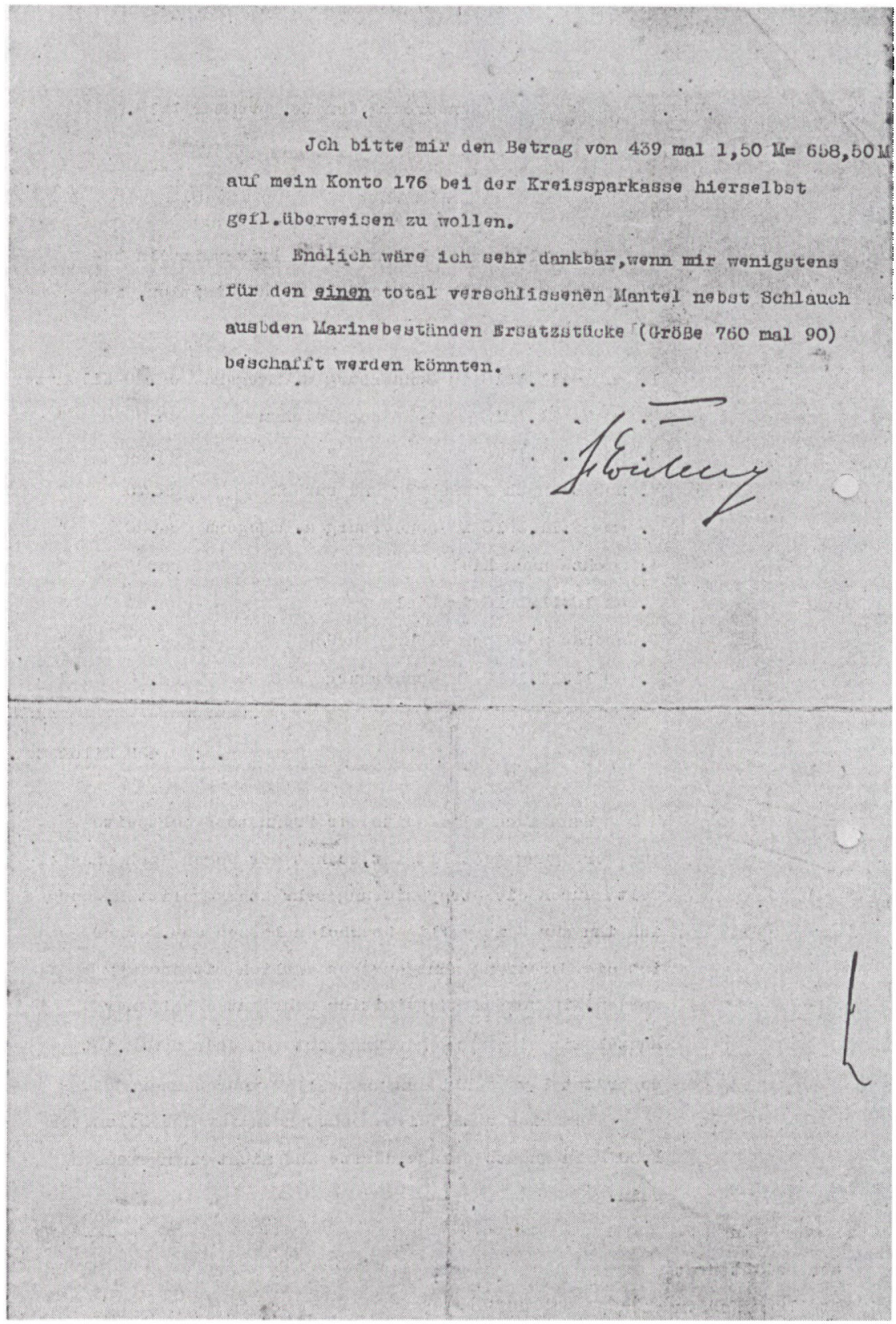

Skrivelse fra landrdd Schönberg til soldaterrddet i Senderborg, hvori han forlanger erstatning for rddets brug af hans bil $i$ revolutionsdagene, og ogsd fik det. Traditionen om, at det var landrddens bil, Topff brugte, er altsd rigtig. (I Senderborg landrdsarkiv nr. 153I) 
i Sønderborg var tilsluttet bevægelsen i Kiel, da man i Årøsund ventede en delegation derfra, der ville diskutere videre anordninger. ${ }^{19}$ Også dette telegram kan have givet indtryk af, at der i Sønderborg blev opereret på en måde, man ikke havde hånd i hanke med i Kiel, og i Årøsund har man åbenbart været i tvivl om, hvad man skulle mene om Sønderborgrådet. Om der kom en delegation afsted til Årøsund, ved vi ikke; men om aftenen den 8 . november var landrådens beslaglagte bil i Flensborg. Om Topff var med i Flensborg, ved vi heller ikke; men der kan have fundet møder sted, der gjorde det klart, hvorledes forholdene blev ordnet andre steder.

I det hele taget må man regne med, at nyhederne hurtigt spredtes $\mathrm{i}$ de dage, også selv om Topff havde lukket for adgangen til postkontoret. Der var bl.a. en hyppig trafik af marineflyvere mellem de forskellige flådestationer, så Noske skulle have haft gode muligheder for at indhente de informationer, han måtte være interesseret $i$.

Om formiddagen den 9. november er det så, at Topff på et soldatermøde giver meddelelse om, at han trækker sig tilbage af helbredsgrunde og overlader sin virksomhed til en kommission. ${ }^{19}$

Hvordan skal man i dag vurdere denne virksomhed på grundlag af det omtalte spredte og mangelfulde kildemateriale? Hvad bliver der af republikken Als?

Med det kildemateriale, der er til rådighed i dag, kan der næppe føres noget bevis for, at Topff skulle have erklæret Als for republik med sig selv som præsident. De proklamationer, han udsendte, peger faktisk i den anden retning. Republikken nævnes heller ikke i Weigleins lange anklagebrev, hvor det havde været naturligt at vente det. Når Topff omtales i Sonderburger Zeitung 1919 er det som »diktator i de første revolutionsdage $\ll{ }^{20}$ Denne betegnelse svarer udmærket til Noskes udsagn om, at Topff ville regere Als alene og til Topffs egen indrømmelse af at have handlet alene. Fra det samtidige kildemateriale er der da også som tidligere omtalt fundet flere eksempler på, at Topff har ført sig frem som den, der bestemte det hele. I forhold til det øvrige Nordslesvig skete der således noget usædvanligt i Sønderborg, selv om der er meget, vi ikke kan fastslå med sikkerhed i dag. At man også var klar over det andre steder, fremgår f.eks. af et telegram 17. november fra Flensborgrådet til Noske. Det hedder heri, at lignende forhold som $i$ Sønderborg her er blevet afværget af "besindige mænd «."

Traditionen om republikken Als rummer således en solid kerne, og det er Topffs egen adfærd i revolutionsdagene, der har lagt grunden til traditionens udvikling. I den korte tid, han ledede soldaterrådet, var 
han i kontakt med mange civilpersoner: embedsmænd, bystyre, bankfolk, Sonderburger Zeitungs folk og en række andre borgere. De fik det indtryk af Topff, der skabte grundlaget for at kalde ham "præsident $\ll$. Det er også meget tænkeligt, at han samtidig har ageret ud fra den betragtning, at Als måtte betragtes som en slags befriet område, hvor kejserdømmet var sat ud af spillet, uden at det udtryktes i nogen egentlig proklamation. En episode, Ernst Christensen refererer fra sin audiens den 7 . november, kunne tyde herpå. En af de audienssøgende var en kaptajn fra et af krigsskibene. "Han bad Topff oplyse sig om, hvilket flag skibet skulle sejle under i morgen til Kiel, om de kunne hejse det tyske orlogsflag? Topff svarede præcist: "Die kaiserlich deutsche Kriegsflotte eksistiert nicht mehr, von jetzt an segeln wir nur unter roten Flagge! ${ }^{22}$ Denne udtalelse faldt mere end to døgn før kejserdømmets fald, og mens landet stadig var $\mathrm{i}$ krig.

Fortolkningen af begivenhederne i revolutionsdagene som republikken Als må være opstået næsten samtidig. Første gang den ses på tryk er i A.V. Karbergs bidrag om Sønderborg i samleværket Sønderjylland som det er. Dette værk udkom i februar 1920 i forbindelse med folkeafstemningen i zone 1. Det er næppe skrevet senere end et år efter revolutionen. Karberg var i 1918 fuldmægtig i Sønderborg Bank, medlem af byrådet fra 1919 og landråd i Sønderborg under Den internationale Kommission 1920. Han kan meget vel selv have truffet Topff, og i hvert fald har han truffet folk, der havde. Karbergs skildring blev trykt i Dybbøl-Posten den 18. februar 1918, så Topff havde faktisk kunnet gøre indsigelse imod den i levende live. Men desværre er der ikke fundet - flere kommentarer fra Topff til revolutionsbegivenhederne efter læserbrevsdebatten i foråret 1919.

Karberg slutter sin korte omtale af republikken Als med følgende ord: "Farcen varede kun kort. De besindigere elementer inden for Socialdemokratiet fik atter overtaget, og rådssystemet indordnedes under de fælles tyske former«.

Det er en præcis beskrivelse af, hvad der skete efter Topffs afgang. Soldaterrådet blev udvidet med 5 medlemmer, og nu skulle der fremtidig være to underskrifter på anordningerne. Dagen efter oprettedes så et arbejderråd som andre steder til at arbejde sammen med soldaterrådet. Hvorledes arbejderbevægelsen har set på Topffs virksomhed, ved vi ikke. Forhandlingsprotokollen for det sønderborgske socialdemokrati fra den tid må anses for at være gået tabt, så der er ingen mulighed for at se, om man havde noteret nogle kommentarer om revolutionen.

Topffs revolutionsindsats sluttede med, at han trak sig tilbage af hel- 
bredsgrunde. Om der også var givet ham tilskyndelser udefra til at foretage dette skridt, kan vi kun gætte på. Noskes erindringer tyder dog på, at der kan være kommet tilskyndelser fra Kiel, måske udsendinge, der kunne forklare, hvorledes man dér mente, revolutionen skulle organiseres. Fra Weigleins læserbrev ved vi desuden, at uviljen mod Topff var stor blandt hærens folk. Også dette kunne vanskeliggøre hans muligheder for at fastholde sin position. Men kendsgerningen er, at efter tre døgn som revolutionsleder var Topff ude af rådsbevægelsen, hvor han ikke mere kom til at spille nogen rolle.

\section{Bruno Topff efter revolutionen}

Det var den 9. november om eftermiddagen, at Bruno Topff trak sig tilbage. Noske fortæller i sine erindringer, at han to gange lod Topff indlægge, før han blev arresteret. Om natten mellem den 9. og 10. november kørte repræsentanter for soldaterrådet til Kiel i landrådens bil. Dér har de formentlig fået nærmere instruktioner om den fremtidige organisering, og de kan have haft Topff med sig. I hvert fald blev han indlagt på Provinzial-Heilanstalt ved Slesvig i dagene fra 11. til 16. november. Arbejder- og soldaterrådet i Sønderborg blev ovenikøbet nødt til at betale regningen senere. ${ }^{24}$ Regningen inkluderede betaling til en privat oppasser, så Topff har været under opsyn.

Ifølge Noskes erindringer var der tale om to indlæggelser af Topff, og han skulle være stukket af hver gang. Den eventuelle anden indlæggelse eksisterer der ikke materiale om. Topff var ikke hjemsendt fra flåden, og en almindelig indlæggelse på lazaret ville ikke resultere $i$ en regning til arbejder- og soldaterrådet. Topff kan være indlagt igen på lazarettet i Sønderborg. I hvert fald blev han arresteret i Sønderborg og derfra overført til Slesvig den 12. december 1918. Skal man tro Noskes erindringer, har arrestationen sammenhæng med, at Topff ikke har kunnet holde sig i ro efter at have trukket sig ud af soldaterrådet, men måske forsøgt fortsat at spille en rolle i den videre udvikling. Derfor kom arrestationen og undersøgelsen mere end en måned efter Topffs afgang. Ifølge Topff selv skyldtes arrestationen anonyme bagvaskere. Hans løsladelse fulgte som omtalt hurtigt. Man skønnede, at hans "forbigående forrykthed" var forsvundet under fængselsopholdet, og Topff gav selv udtryk for det over for Noske. Han blev så afhentet af sin kone. Det var ikke en særlig heroisk afslutning på revolutionsdagene, men selvfølgelig klogt af Topff at bøje sig for den ret frygtindgydende 
guvernør Noske. Noske forlod kort efter posten som guvernør for at blive rigsværnsminister. Det var under hans ledelse, bekæmpelsen af de revolutionære bevægelser skete i den følgende tid.

\section{Topffs virke i Sønderborg 1919-20}

Topff var nu frikendt for de anklager, vi ikke kender den præcise formulering af. Han var imidlertid fortsat ikke hjemsendt fra flåden. Det varede formentlig et par måneder endnu. Efter hjemsendelsen valgte han at slå sig ned i Sønderborg, hvor han blev anmeldt til kommunen som tilflyttet den 6. marts 1919. Den 26. maj sluttede hans hustru Anna sig til ham. Topff boede fire forskellige steder i Sønderborg, sidst i Perlegade, hvor han flyttede til en månedstid før sin død. ${ }^{26}$

Efter overleveringen skal Topff have forsøgt at leve af sit gamle erhverv som skrædder; men hvor meget det blev til, er vist tvivlsomt. Den 19. oktober 1919 søgte han understøttelse fra Røde Kors Komitéen for vanføre og lemlæstede Krigsinvalider under Den sønderjydske Fond. Her angav han, at han ikke havde kunnet genoptage sin tidligere virksomhed, da han til stadighed måtte være i frisk luft. Han oplyste desuden, at han havde en "lungelidelse ifølge krigsstrabadser", en hjertelidelse og nervøse tilstande. Han fik i forvejen $60 \%$ invalidegodtgørelse. ${ }^{27}$ Måske er det denne godtgørelse, han mest har levet af. I Sonderburger Zeitung den 8 . juli 1919 betegnes han som automobilhandler, og redaktør Kai Edvard Larsen, der selv har truffet Topff, mener, at han i den sidste tid mest ernærede sig ved smughandel, og at mange formummede skikkelser færdedes i hans hjem. ${ }^{28}$ Dette kan dog, som så meget andet, ikke verificeres.

Derimod er det faktisk muligt at sige noget om Topffs politiske virksomhed i Sønderborg. Kaj Nissen formoder i sin artikel fra 1965, at Topff den 9. november 1918 trak sig tilbage $»$ med rolighed i sindet $\ll^{29}$ Men den vurdering skyldes nok, at Nissens kildestudier er indskrænket til selve revolutionsdagene. I løbet af 1919 udviklede Topff et stærkt politisk engagement på venstrefløjen, som han forfægtede med lidenskab og rastløs energi, så vidt man kan dømme efter avisomtalerne, der er den eneste kilde til dette spørgsmål.

Allerede kort efter sin frigivelse deltog Topff i et politisk møde i Sønderborg. Det var i en socialdemokratisk valgforsamling 8. januar 1919 før valget til Nationalforsamlingen. Her anføres han som én af dem, der tog ordet »fra socialdemokratisk side $\ll^{30}$ I marts erklærede han så i sit tidligere citerede læserbrev, at han var fuldkommen partiløs; men 
det kan naturligvis være en erklæring, der var fremtvunget af den pressede situation, han følte sig i på det tidspunkt.

Socialdemokratiet, SPD, var på det tidspunkt det eneste arbejderparti, der havde organisationer i Nordslesvig. Men sidst på foråret og i begyndelsen af sommeren 1919 begyndte både det uafhængige socialdemokrati, USPD, og kommunisterne, KPD (det tidligere Spartakusbund) at agitere i Nordslesvig for oprettelse af partiforeninger. Topff tilsluttede sig USPD, der indtog en mellemposition mellem SPD og $\mathrm{KPD}$, men var meget kritisk over for regeringspartiet, "regeringssocialisterne $\lll$, der nu effektivt havde bremset den videre socialisering $\mathrm{i}$ Tyskland. Der er ingen belæg for, at Topff nogensinde skal have været spartakist. $^{31}$

USPD afholdt sit første hvervemøde i Sønderborg den 13. juni 1919 med en hovedtaler fra Kiel, der talte om de uafhængige socialdemokrater og socialismen med voldsomme angreb på regeringen og Noske. Under diskussionen støttede Topff taleren.$^{32}$ Kort efter blev der stiftet en lokalafdeling af USPD med Topff som formand. Den skal have fået 70 medlemmer med det samme. ${ }^{33}$ En ny offentlig hverveforsamling blev holdt den 7. juli. Taleren Frasunkiewiecz fra Bremen talte bl.a. for proletariatets diktatur gennem rådssystemet som overgang til den socialdemokratiske fremtidsstat. Samtidig betonede han, at de uafhængige ikke var tilhængere af spartakisternes kupteorier. ${ }^{34}$

Senere på måneden fremsatte Topff forskellige synspunkter $\mathrm{i}$ et læserbrev i Sonderburger Zeitung med udgangspunkt i et omstridt besøg af danske spejdere. Han angreb den tyske kritik af dette besøg og erklærede sig imod enhver form for had mellem folkene. Det var beklageligt, at danske og tyske arbejdere ikke havde kunnet danne én organisation. ${ }^{35}$ Det var på denne tid, at mange dansksindede arbejdere organiserede sig i Sønderjysk Arbejderforening.

I Nordslesvig fandt den stærkt splittede arbejderbevægelse dog sammen flere gange i 1919 i aktioner og demonstrationer for forbedring af levnedsmiddelsituationen. ${ }^{36}$ I Sønderborg fandt en sådan demonstrátionsforsamling sted den 16 . august. Arrangørerne angaves at være fagforeningerne, SPD, USPD, KPD og den danske arbejderforening. Mødet, der varede et kvarter, havde Topff som hovedtaler. Forsamlingen skulle hovedsagelig protestere mod en nedsættelse af smørrationen. ${ }^{37}$ Om dette krav blev gennemført, er ikke klarlagt. Lignende demonstrationer fandt ikke sted senere i Sønderborg. Dette var formentlig Topffs sidste vigtige offentlige fremtræden i Sønderborg.

Om efteråret skal han have hjulpet de arbejdsløse med at få hævet 


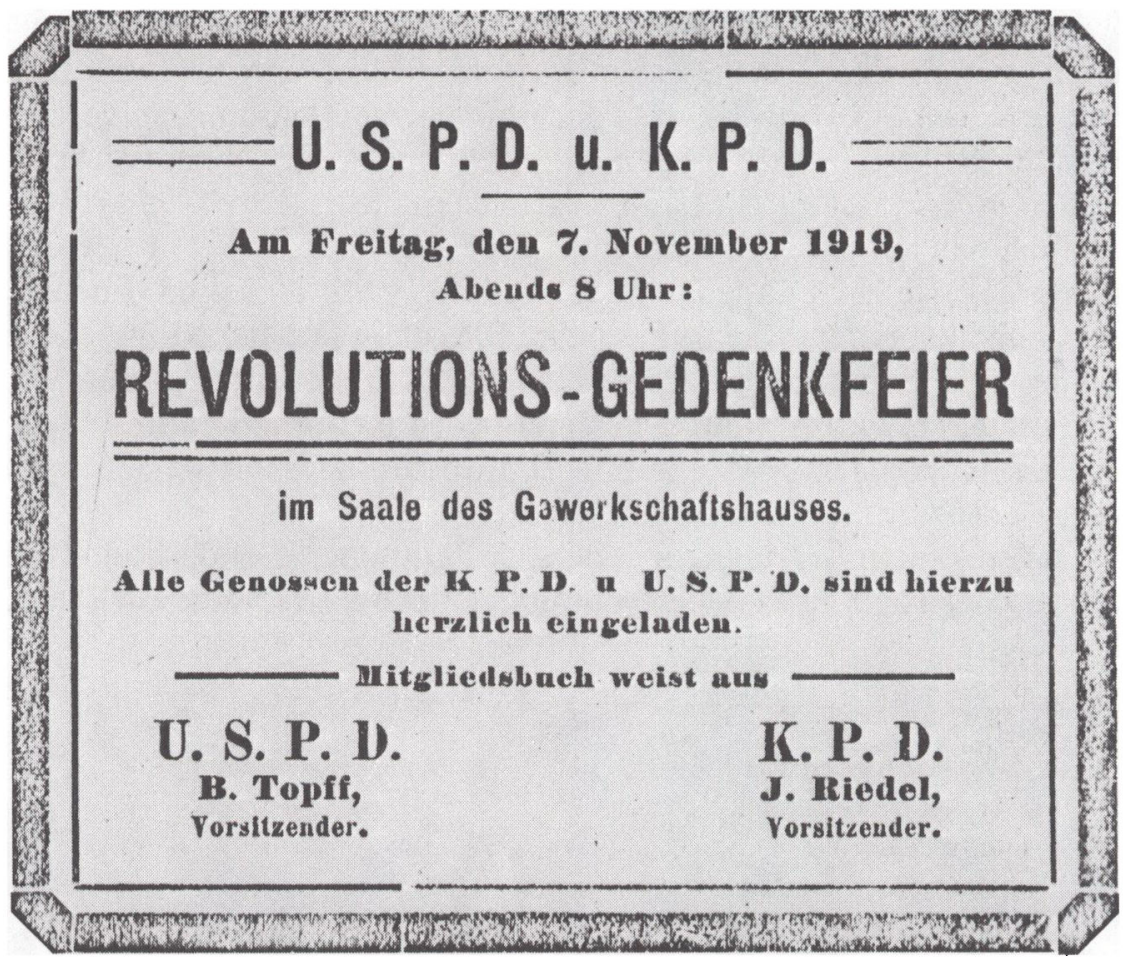

Annonce i Sonderburger Zeitung fra 6. november 1919 med indbydelse til en mindefest for den tyske revolution. Bruno Topff, der pd dette tidspunkt var formand for venstrefløjspartiet de uafhangige socialdemokrater indbyder til mødet sammen med formanden for den kommunistiske partiforening.

deres understøttelser. De arbejdsløse havde ligesom mange andre steder dannet en organisation for at varetage deres økonomiske interesser, og Topff blev i en forsamling betroet at forelægge deres krav for magistraten. ${ }^{38}$

Etårsdagen for den tyske revolution blev fejret i fællesskab af KPD og USPD ved en $»$ Revolutions-Gedenkfeier « $\mathrm{i}$ fagforeningshuset den 7. november. Forløbet af den hensatte Topff i en sådan ophidselse, at han måtte skrive et nyt læserbrev til Sonderburger Zeitung. Mødet blev åbnet af kommunisternes formand, fisker J. Riedel, og taleren var den kommunistiske værftsarbejder Heilmann fra Flensborg. Han skal, bl.a. have sagt, at socialiseringen måtte gennemføres efter det russiske mønster. Topff hævder at være gået efter 10 minutters forløb, og hans læserbrev er dateret samme dag, den 7 . Indledningen på læserbrevet 
lyder således på originalsproget: "Der proletarische Redner "als solcher" trat an das Pult »als solcher" und eröffnete seine Rede »als solche« mit dem Hinweis, dass der proletarische Korbmachergeselle Gustav Noske »als solcher« den proletarischen Arbeiter »als solchen« in den proletarischen Hinteren wals solchen « tritt. (Brrr!) Und das 15 Mal am Abend! Au!!!« Det fremgår af det følgende, at det er talerens dannelsesniveau og åndelige horisont, han er utilfreds med. En taler som han nedbryder, hvad de intellektuelle i hans parti har opbygget, og kommer der flere af den slags, må USPD tage kraftigt afstand fra KPD. ${ }^{39}$ Harmen hos Topff synes mere at gå på formen end på noget politisk indhold, og måske kunne Topff bedre have set sig selv som taler ved denne revolutionsmindefest.

Der er ikke fundet referater af flere USPD-møder i Sønderborg. Den sidste gang Topff vides at have optrådt ved et politisk møde var ved et

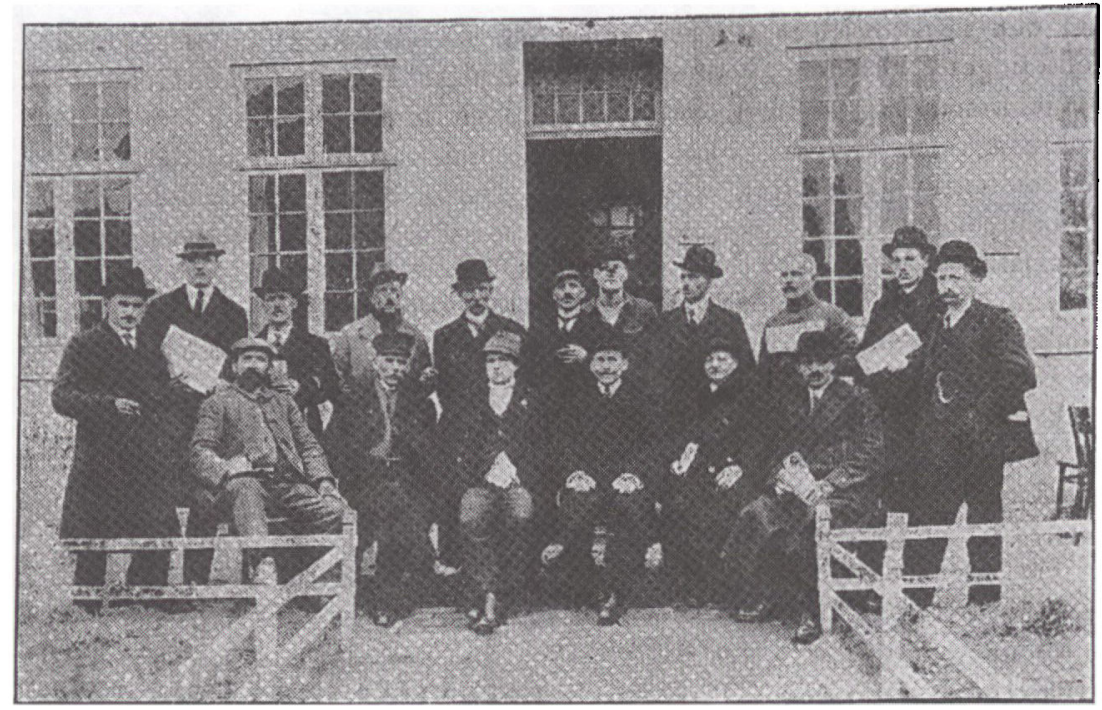

Representanter for 1 . Zones uafhengige jog kommunistiske Partiloreninger, samlet I Tinglev til Konterence den 2i. Febr. Pat Ierste Rekke ses siddende, som Nr. 2 og 47fra hojre, vore Kammerater Edv. Jensen og Gerh. Richter og yderst til holre Partifielte Wauer, Tonder der bl. a. var Deltager $I$ Odense-Kongressen.

Deltagerne i Tinglevkonferencen den 22. februar 1920, hvor de uafhangige socialdemokratiske og de kommunistiske partiforeninger vedtog at slutte sig til det danske venstresocialistiske parti efter genforeningen. Formentlig var Topff ikke langere politisk aktiv pd dette tidspunkt og derfor nappe mellem personerne på billedet. (Efter Arbejdet den 6. marts 1920) 
socialdemokratisk møde den 5. januar 1920. Her talte P. Michelsen, Flensborg, om den nye tyske republik. Ved diskussionen tog Topff ordet og bebrejdede flertalssocialisterne beskidte forretninger med borgerlige partier. Protestråb fra salen ophidsede ham kun yderligere. Til sidst skal Michelsen have nedgjort Topff til forsamlingens jubel. ${ }^{40}$

Topff synes ellers ikke at have fortsat sin politiske virksomhed i 1920. De spredte indtryk, man kan samle om denne virksomhed, vidner om stærkt engagement og selvhævdelse, måske ikke altid så megen ligevægt samt forholdsvis beskedne resultater. Topff forblev i en ret perifer position i arbejderbevægelsen i Sønderborg, hvor SPD trods al splittelse forblev det dominerende parti.

Om Topffs parti, USPD, skal oplyses, at det ophørte at eksistere i 1922, og medlemmerne gik dels til SPD, dels til kommunisterne. Partiforeningerne i Nordslesvig besluttede på en konference i Tinglev sammen med de kommunistiske foreninger den 22. februar 1920, at man ved genforeningen ville slutte sig til det danske, venstresocialistiske parti (det senere kommunistiske parti). ${ }^{11}$ Om Topff deltog i denne konference, ved vi ikke. I den store strejkebevægelse op til genforeningen er hans navn ikke fremme i nogen forbindelse, og han var således ikke mellem de tilflyttede arbejderførere, der blev udvist af Den internationale Kommission. Det blev f.eks. murer Chr. Brockstedt, Sønderborg, der havde været med til at grundlægge USPD-foreningen.

\section{Topffs sidste tid}

Man må antage, at Topffs stadig dårligere helbred omsider har tvunget ham bort fra offentlig virksomhed. Den 31. december 1919 beklagede han sig i et læserbrev over utilstrækkelig sygekassehjælp. Det "gamle, forstokkede bureaukrati« levede videre trods den nye tid. ${ }^{42}$

Traditionen vil vide, at Topff på et tidspunkt var på kurophold i Silkeborg. Dette har ikke kunnet bekræftes; men formentlig har det først kunnet finde sted efter genforeningen. Den 5 . november $1920 \mathrm{blev}$ han indlagt på hospitalsafdelingen på Krigsinvalideskolen i Sønderborg wyderst medtaget, lidende af Tub. peritonæi (bughindetuberkulose). Faldt hurtig af og døde 9 . november $1920 \ll^{43}$

De efterladte annoncerede dødsfaldet $\mathrm{i}$ en stor tospaltet dødsannonce i Sonderburger Zeitung den 11. november 1920. Hans lig blev ført bort med Flensborgdamperen og siden begravet i Berlin. Hans enke flyttede fra Sønderborg til Berlin samme dag. De efterlod sig ingen børn. 


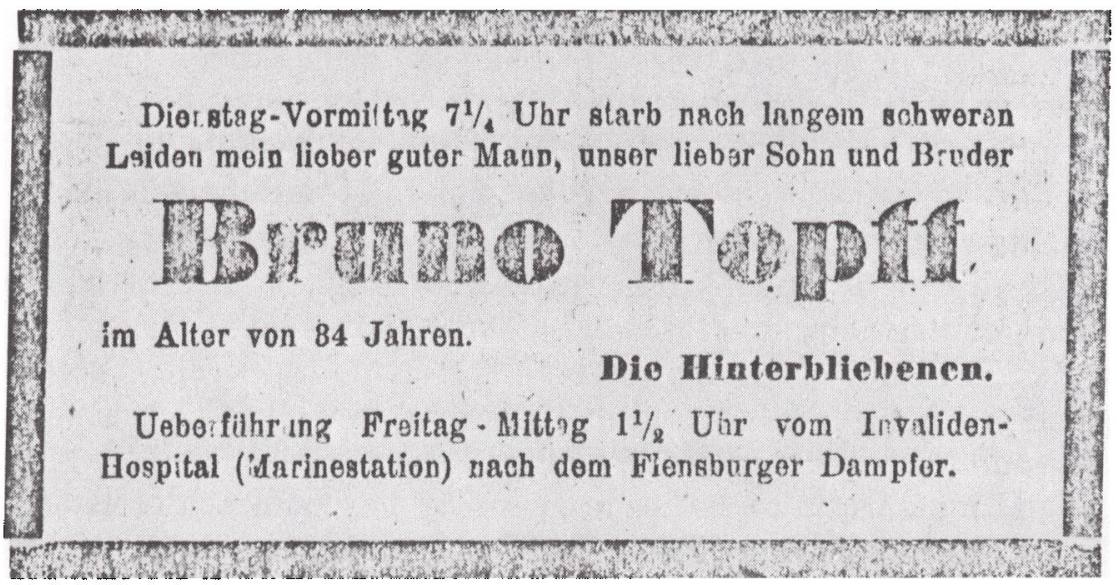

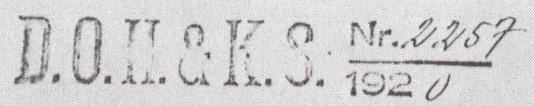

Für die vielen Beweise wohltuender Teilnahme bei dem Hinscheiden meines geliebten Mannes, unseres teuren Sohnes und Bruders

\section{Bruno Topff}

sprechen wir hiermit unseren tiefgefühlten Dank aus.

Im Namen aller

\section{Frau Anni Topff geb. Wittig}

Berlin W 57, 25. November 1920

Blumenthalstratie 4

Bruno Topff dode på Krigsinvalideskolens hospital den 9. november 1920. Han blev ikke begravet $i$ Sønderborg, men $i$ Berlin. $\emptyset$ verst ses dødsannoncen $i$ Sonderburger Zeitung den 11. november 1920, nederst enkens takkekort, som bl.a. er sendt til Krigsinvalideskolen. I et folgebrev takker hun varmt for den gode pleje, hendes mand har fået under indlaggelsen. (Krigsinvalideskolens arkiv) 


\section{Slutning}

Således afsluttedes Bruno Topffs korte liv. Han var ikke en stor politiker, endsige statsmand, og hans indsats for arbejderbevægelsen i Sønderborg blev kortvarig og af begrænset betydning. Hans virke appellerer måske mere til eftertidens overbærenhed og medlidenhed end til den store beundring. Alligevel er der i 1978 i Sønderborg stiftet et selskab, der bærer hans navn, Bruno Topff Selskabet. I en efterskrift til Robert Huhles bog fortælles om selskabet, og man forstår, at en væsentlig grund til dets eksistens er, at man vil ære Topff, fordi han "sørgede i væsentlig grad for, at revolutionen i Sønderborg blev en fredelig affære«. Det er måske en lidt søgt begrundelse for at fordybe sig i en farverig episode i byens historie. Som det er omtalt ovenfor, var forløbet også fredeligt andre steder i landsdelen. I sammenligning hermed er det faktisk kun forløbet i Sønderborg, der udviser atypiske, lidt "ufredelige«, om end ublodige træk. Men Topff har da nu opnået en anseelse og respekt, han ikke nød i levende live.

Selskabet har endog fået et hjemsted på kasernen i Sønderborg. Ved Topffs audiensværelse er der nu takket være selskabet opsat en mindeplade for hans virke i revolutionsdagene. Topff havde næppe kunnet forestille sig den ære efter at have sat officererne ud af spillet i 1918! Det hedder i efterskriften, at hvert år omkring revolutionsdagen "samles Bruno Topff Selskabet i Brunos værelse, der holdes en nydelig og ikke for tung tale, selskabets medlemmer er alle udstyret med marinehuer, og en lille rød klud på marinehuen dokumenterer, at alle er revolutionære i Bruno Topffs ånd fra november 1918«. Efter mindehøjtideligheden "serveres en kraftig marineret..."

Selskabet har indlagt sig særlig fortjeneste ved at opspore Bruno Topffs grav i Berlin, så medlemmerne har kunnet foretage en slags pilgrimsrejse hertil. Tilsyneladende har venstresocialisten Topff ikke vendt sig i sin grav ved denne hyldest fra mange gode mænd, der for en stor dels vedkommende - må man da antage - politisk står hans anskuelser fjernt.

Denne sene anerkendelse skal være Topff velundt. Men man tænker uvilkårligt på de mange, der ofte under store personlige ofre opbyggede den nordslesvigske arbejderbevægelse og i mange år både før og efter genforeningen havde det daglige ikke-spektakulære slid for at sikre arbejdernes indflydelse på politiske og sociale forhold. Måske var det nok så naturligt at samle materiale ind om dem og måske også mødes og mindes dem engang imellem med »en kraftig ret«. 


\section{LITTERATUR OG TRYKTE KILDER}

Kursiv angiver forkortelser $\mathrm{i}$ henvisninger.

Dorrit Andersen: Rảdsbevagelsen i Nordslesvig 1918-20. Sønderjyske Årbøger 1972, s. 147-85.

Ernst Christensen: Hvad der skete for ti Aar siden. Danebod Hojskole 1928, s. 42-54.

Dirk Dähnhardt: Revolution in Kiel. Der Übergang vom Kaiserreich zur Weimarer Republik 1918/19. Neumünster 1978.

Robert Huhle: Bruno Gustav Eugen Topff og revolutionen i Sønderborg. Sønderborg 1984.

Kildekritisk tekstsamling. Udgivet af Jørgen Fink, Jens Chr. Manniche, Helge Paludan. Arhus 1978.

Anker Kirkeby og Erik H. Schack: Sønderjylland som det er. 1920.

Kai Edvard Larsen: Et halvt århundrede i grænselandet. Sønderborg 1969.

Frede Nielsen: Fra Udmark til Forpost. Den sønderjydske Arbejderbevægelses Historie. 1938.

Kaj Rolfsen Nissen: Problemer omkring »Præsident« Topff. Sønderjyske Årbøger 1965, s. 83-103.

Gustav Noske: Von Kiel bis Kapp. Zur Geschichte der deutschen Revolution. 1920.

J. Slettebo: Strejker i Sønderborg 1920. Fra Als og Sundeved 1969, s. 72-88.

A. Thyssen: Omkring »Præsident $«$ Topff, Sønderborg. Sønderjyske Àrbøger 1966.

s. 204-08.

Aviser:

Arbejdet. Organ for Danmarks venstresocialistiske Parti.

Dybbøl-Posten.

Republik. Organ der Unabhängigen Sozialdemokratische Partei für die Provinz Schleswig-Holstein.

Sonderburger Zeitung.

Forkortelser i øvrigt i henvisninger:

LAS = Landesarchiv Schleswig-Holstein, Slesvig, LAẢ = Landsarkivet for de sønderjyske landsdele, Åbenrå, RA = Rigsarkivet, København, SJy Årb = Sønderjyske Årbøger, $\mathrm{SZ}=$ Sonderburger Zeitung.

\section{HENVISNINGER OG NOTER}

1. Bernhard Rausch: Am Springquell der Revolution. Die Kieler Matrosenerhebung. Kiel 1918. S. 5. Forfatteren var chefredaktør ved SPD-avisen Schleswig-Holsteinische Volkszeitung i Kiel.

2. Dähnhardt s. $81,120 \mathrm{f}$.

3. Rues (?): Meine Eindrücke über die Bildung von Soldaten- und Arbeiterräten in Flensburg, s. 4. Stadtarchiv Flensburg Hs. 11/26.

4. Von Kiel Bis Kapp s. 32: »Einen Mann, der auf Alsen sein Wesen trieb, liess ich zweimal ins Lazarett bringen, da er infolge Mangels an Schlaf ganz unzurechnungsfähig geworden war. Er brannte jedesmal wieder durch. Zum drittenmal liess ich ihn mir durch Bewaffnete vorführen und dann in Arrest sperren. Die Untersuchung ergab nicht, dass er ernste Straftaten verübt hatte. Dass er die Insel Alsen allein regieren wollte, war nur ein Ausfluss vorübergehender Verrücktheit. Der Kriegsge- 
richtsrat schlug mit vor, ihn zu entlassen, seine Frau sei gekommen, um ihn mit nach Hause zu nehmen. Am nächsten Tage erschien er in blitzsauberer Uniform bei mit und erklärte: "Herr Gouverneur haben mich eingesperrt. Dafür bedanke ich mich. Jetzt bin ich wieder ganz vernünftig«. Ein Jahr später habe ich von ihm einen sehr netten Brief erhalten. - Bei anderen wilden Männern genügte es, dass ich sie mir vorführen liess und mit einsperren bedrohte, um sie manierlich werden zu lassen«.

5. SZ 7.-11.11. 1918.

6. SZ 2.4. 1919.

7. D.v.s. borgerkrigstilstanden i store dele af Tyskland januar-maj 1919.

8. SZ 4.4. 1919.

9. SZ 10.4. og 16.4. 1919.

10. SJy Ȧrb 1966, s. 206. Thyssen var på dette tidspunkt søkadet på reservesøofficersskolen i Sønderborg. Han henlægger revolutionen til den 7. november, formentlig fordi denne fejl findes i Rolfsen Nissens artikel, som han har læst, inden han skrev sin egen.

11. Danebod Højskole 1928, s. 43 f.

12. Landråd Schönberg til soldaterrådet 14.11. 1918. I Sønderborg landrådsarkiv nr. 1531 (LAA).

13. Dähnhardt s. 90.

14. Danebod Højskole 1928, s. 46 f.

15. Do. s. 45 ff. I en skrivelse fra landråden i Flensborg til regeringspræsidenten 12.11 . 1918 omtales også udførselsindskrænkninger for levnedsmidler og landbrugsvarer $\mathrm{i}$ Sønderborg (LAS Abt. 320, nr. 394).

16. Telegrammet i Bundesarchiv, Militärarchiv, Freiburg. F 1663/PG 91862. Meldungen über Bildung von Soldatenräte in Schleswig-Holstein und im Reiche, nr. 26. (Kopier i RA, Håndskriftsamlingen XVI, Danica 203, pk. 37, læg 439). Rådsbevægelsen s. 152.

18. Militärarchiv som i note $16, \mathrm{nr} .17$.

19. SZ 11.11. 1919.

20. F.eks. SZ 8.7. 1919.

21. Militärarchiv som note 16, nr. 24 .

22. Danebod Højskole 1928, s. 46.

23. Sønderjylland som det er, s. 109.

24. Landeshauptmann Schleswig-Holstein til soldaterrådet i Sønderborg 11.3. 1919. I Sønderborg landrådsarkiv nr. 1531 (LAA).

25. I soldaterrådets regnskab står udgiften under denne betegnelse »der inhaftierte Oberhandwerkergast Topf wird nach Schleswig überführt«. Sønderborg landrådsarkiv nr. 1531 (LAA).

26. Melderregister for Sønderborg kommune (LAA).

27. Krigsinvalideskolens arkiv (LAẢ). Ansøgninger nr. 1901 (pk. 14). Resultatet af ansøgningen fremgår ikke.

28. Kai Edvard Larsen: Et halvt århundrede i grænselandet. s. 50.

29. SJy Årb 1965 , s. 88.

30. SZ 11.1. 1919.

31. Det hævdes således hos Huhle s. 11.

32. SZ 14.6. 1919.

33. Republik 7.7. 1919.

34. SZ 8.7. 1919 og Republik 11.7. 1919.

35. SZ 29.7. 1919.

36. Rådsbevægelsen s. $164 \mathrm{ff}$. 
37. SZ 18.8. 1919.

38. Republik 6.11. 1919.

39. SZ 6., 8. og 10.11. 1919.

40. SZ 6.1. 1920. 9.1. annonceres en USPD-folkeforsamling; men der er ikke fundet noget referat af den.

41. Arbejdet 28.2. 1920.

42. SZ 31.12. 1919. Videre diskussion herom i SZ 3., 6. og 16.1. 1920.

43. Krigsinvalideskolen i Sønderborg 26. September 1920 - 19. maj 1925. Beretning afgiven af Skolens Direktion. 1926. S. 52. 